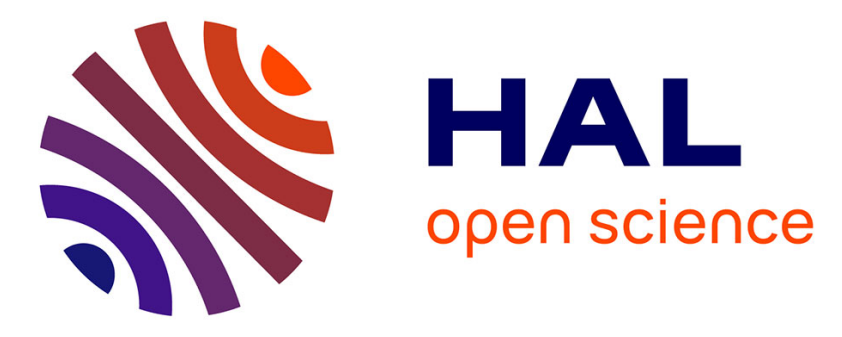

\title{
Cyclodextrin-Assisted Hierarchical Aggregation of Dawson-type Polyoxometalate in the Presence of Re6Se8 Based Clusters
}

Anton Ivanov, Clement Falaise, Alexandra A Shmakova, Nathalie Leclerc-Laronze, Stéphane Cordier, Yann Molard, Yuri V Mironov, Michael A. Shestopalov, Pavel A. Abramov, Maxim N. Sokolov, et al.

\section{To cite this version:}

Anton Ivanov, Clement Falaise, Alexandra A Shmakova, Nathalie Leclerc-Laronze, Stéphane Cordier, et al.. Cyclodextrin-Assisted Hierarchical Aggregation of Dawson-type Polyoxometalate in the Presence of Re6Se8 Based Clusters. Inorganic Chemistry, 2020, 59 (16), pp.11396-11406. 10.1021/acs.inorgchem.0c01160 . hal-02930227

\section{HAL Id: hal-02930227 https://hal.science/hal-02930227}

Submitted on 24 Nov 2020

HAL is a multi-disciplinary open access archive for the deposit and dissemination of scientific research documents, whether they are published or not. The documents may come from teaching and research institutions in France or abroad, or from public or private research centers.
L'archive ouverte pluridisciplinaire HAL, est destinée au dépôt et à la diffusion de documents scientifiques de niveau recherche, publiés ou non, émanant des établissements d'enseignement et de recherche français ou étrangers, des laboratoires publics ou privés. 


\title{
Cyclodextrin-Assisted Hierarchical Aggregation of Dawson-type
}

\section{Polyoxometalate in the Presence of $\left\{\mathrm{Re}_{6} \mathrm{Se} 8\right\}$ Based Clusters}

\author{
Anton A. Ivanov ${ }_{, a b}^{a b}$ Clément Falaise, ${ }_{a, *}$ Alexandra A. Shmakova ${ }^{a b}$ Nathalie Leclerc, ${ }^{a}$ Stéphane \\ Cordier, Yann Molard, 'Yuri V. Mironov, ${ }^{,}$Michael A. Shestopalov, ${ }^{b}$ Pavel A. Abramov, ${ }^{\text {,dd }}$ Maxim \\ N. Sokolov, ${ }^{b}$ Mohamed Haouas, ${ }^{,}$and Emmanuel Cadot ${ }^{*}$
}

· Institut Lavoisier de Versailles, UMR 8180 CNRS, UVSQ, Université Paris-Saclay, Versailles, France.

' Nikolaev Institute of Inorganic Chemistry SB RAS, Novosibirsk, 630090, Russia.

- Institut des Sciences Chimiques de Rennes, UMR 6226 CNRS, Université de Rennes 1, Rennes, France

${ }^{\triangleleft}$ South Ural State University, Prospekt Lenina, 76, Chelyabinsk, Russia, 454080 


\section{ABSTRACT:}

The association of metallic clusters (CLUS) and polyoxometalates (POM) into hierarchical architectures is achieved using $\gamma$-cyclodextrin $(\gamma-\mathrm{CD})$ as supramolecular connector. The new self-assembled systems, so-called CLUSPOM, are formed from Dawson-type polyoxometalate $\left[\mathrm{P}_{2} \mathrm{~W}_{18} \mathrm{O}_{62}\right]^{6-}$ and electron-rich rhenium clusters. It is worth noting that a cluster-based cation $\left[\left\{\mathrm{Re}_{6} \mathrm{Se}_{8}\right\}\left(\mathrm{H}_{2} \mathrm{O}\right)_{6}\right]^{2+}$ on one hand and a cluster-based anion on the other hand $\left[\left\{\mathrm{Re}_{6} \mathrm{Se}_{8}\right\}(\mathrm{CN})_{6}\right]^{+}$can be associated with the anionic POM. In the absence of the supramolecular connector, a 'CLUSPOM salt' was obtained from aqueous solution of the cationic cluster and the polyoxometalate. In this solid, the arrangement between the polymetallic building blocks is mainly governed by long-range coulombic interactions. In presence of $\gamma-\mathrm{CD}$, the Dawson anion and the cationic cluster are assembled differently, forming a hierarchical supramolecular solid, $\mathrm{K}_{2}\left[\left\{\mathrm{Re}_{6} \mathrm{Se}_{8}\right\}\left(\mathrm{H}_{2} \mathrm{O}\right)_{6}\right]_{2}\left\{\left[\mathrm{P}_{2} \mathrm{~W}_{18} \mathrm{O}_{62}\right] @ 2 \gamma-\mathrm{CD}\right\} \cdot 42 \mathrm{H}_{2} \mathrm{O}$, where the organic macrocycle acts as a ditopic linker between the inorganic building blocks. In such an edifice, the short-range molecular recognition dominates the long-range coulombic interactions leading to a specific 3D organization. Interestingly, the assembling of anionic $\left[\mathrm{P}_{2} \mathrm{~W}_{18} \mathrm{O}_{62}\right]^{6-}$ with the anionic rhenium cluster $\left[\left\{\mathrm{Re}_{6} \mathrm{Se}_{8}\right\}(\mathrm{CN})_{6}\right]^{+}$is also achieved with $\gamma$-CD despite the repulsive forces between the nano-sized anions. The resulting solid, $\mathrm{K}_{10}\left\{\left[\left\{\mathrm{Re}_{6} \mathrm{Se}_{8}\right\}(\mathrm{CN})_{6}\right] @ 2 \gamma-\mathrm{CD}\right\}\left[\mathrm{P}_{2} \mathrm{~W}_{18} \mathrm{O}_{6}\right] \bullet 33 \mathrm{H}_{2} \mathrm{O}$, is built from 1:2 inclusion complexes $\left\{\left[\left\{\operatorname{Re}_{6} \mathrm{Se}_{8}\right\}(\mathrm{CN})_{6}\right] @ 2 \gamma-\mathrm{CD}\right\}^{+}$linked by a POM unit interacting with the exterior wall of the organic macrocycle. Multinuclear NMR and small-angle X-ray scattering (SAXS) investigations support supramolecular pre-organization in aqueous solution prior to crystallization. 


\section{INTRODUCTION}

Discrete polymetallic entities exhibit prodigious structural diversity, chemical composition and properties, making them particularly appealing as preformed building units for tailoring innovative materials. ${ }^{1-5}$ The crystal engineering methodology taking benefits from the supramolecular recognition processes between complementary nano-sized entities attracts considerable attention due to its capacity to create synergies relevant for applications in optic, catalysis, separation, gas adsorption, etc. ${ }^{6-11}$ These supramolecular mixed polymetallic-scaffolds based solids are generally built from large cationic and anionic complexes, and therefore can be viewed as salts of complexes wherein the anionic partners are spatially organized to minimize coulombic repulsions, as observed in many examples. ${ }^{12-18}$ However, the structural organization obeys sometimes to more intricate rules. For instance, aggregates built from equally charged polymetallic entities are observed in few materials. ${ }^{19-21}$ This underlines that short-range supramolecular interactions, such as hydrogen bonds or van der Waals contacts must be taken into account as additional forces that drive the assembly of the preformed inorganic units in the solid-state. Therefore, mastering the conglomerate of collective weak forces during the aggregation processes could offer novel opportunities in the crystal engineering of mixed cluster solids such as, for instance, i) using neutral polymetallic entities, ${ }^{11}$ ii) assembling cationic (or anionic) building blocks together or even better iii) programming the assembly into predicted architectures.

Among the library of well-defined metal-containing aggregates, polyoxometalates (POMs), that correspond to anionic metal-oxo clusters of mainly group VI elements in their higher oxidation states (e.g. $\mathrm{Mo}^{6+}$ and $\mathrm{W}^{6+}$ ), exhibit striking redox ${ }^{4}$ and catalytic properties ${ }^{22}$, and therefore, are relevant components to design advanced materials. Consequently, POMs are 
widely used in the preparation of large anion-cation materials, and have been combined with $\mathrm{Al}(\mathrm{III})$ polycations, ${ }^{12,23-26}$ trinuclear $\mathrm{Ru}(\mathrm{III})$ cations,${ }^{27}$ 3d-metal based macrocations ${ }^{16,17,28-34}$, gold $^{13,21,35-40}$ and silver ${ }^{9,19,20}$ clusters. The structural organization of these solids results from a sophisticated balance between long-range and short-range bonding interactions, making any predictions of the crystalline arrangement highly challenging.

Gamma-cyclodextrin $(\gamma-\mathrm{CD})$ is a water-soluble macrocyclic polysaccharide constituted of 8 glucopyranose units, exhibiting a rim lined by the eight hydroxymethylene groups (primary face) and a larger rim lined by sixteen hydroxyl groups (secondary face). Each $\gamma$-CD face is able to interact with polyoxometalates or other ionic polynuclear entities in aqueous solution leading to highly stable supramolecular adducts. ${ }^{41-48}$ The main driving force that governs this recognition process has been identified as resulting from a water structure recovery process induced by the chaotropic nature of the solvated macro-ions. ${ }^{49}$

We reported recently that $\gamma$-CD can act as a ditopic supramolecular linker to associate in a predictive way the Dawson-type POM $\left[\mathrm{P}_{2} \mathrm{~W}_{18} \mathrm{O}_{62}\right]^{6-}$ and the tantalum octahedral cluster $\left[\left\{\mathrm{Ta}_{6} \mathrm{Br}_{12}\right\}\left(\mathrm{H}_{2} \mathrm{O}\right)_{6}\right]^{2+}$ to give the first example of a CLUSPOM compound, obtainable either as hydrogel or highly ordered crystal. ${ }^{41}$ This auspicious result opened the possibility to combine an electron-rich cluster (CLUS; as donor) with an electron-poor polyoxometalate (POM; as acceptor), and encouraged us to explore further the crystal engineering of CLUSPOM solids using other metal atom cluster types like the face-capped cluster-based units bearing different charge and carrying different physical properties than $\left[\left\{\mathrm{Ta}_{6} \mathrm{Br}_{12}\right\}\left(\mathrm{H}_{2} \mathrm{O}\right)_{6}\right]^{2+}$. 


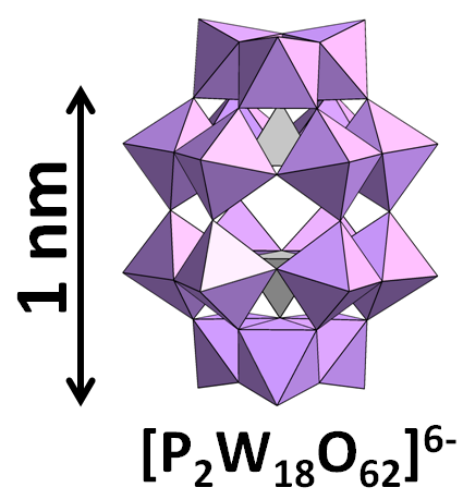

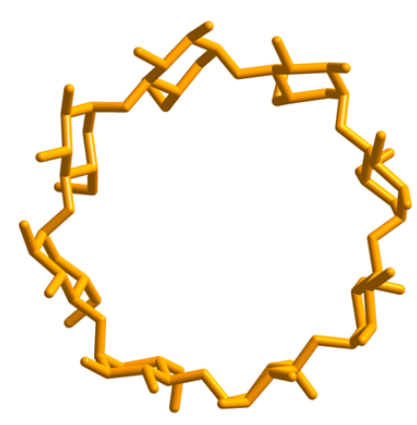

CD

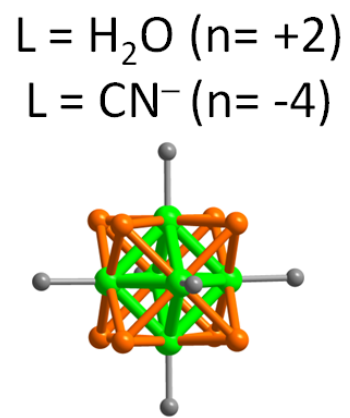

$\left[\left\{\operatorname{Re}_{6} \mathrm{Se}_{8}\right\} \mathrm{L}_{6}\right]^{\mathrm{n}}$

Figure 1. (a) Structural representation of the molecular components used for designing supramolecular inter-cluster compounds. The inorganic building blocks are Dawson-type polyoxometalate $\left[\mathrm{P}_{2} \mathrm{~W}_{18} \mathrm{O}_{62}\right]^{6-}$ and octahedral rhenium clusters $\left[\left\{\mathrm{Re}_{6} \mathrm{Se}_{8}\right\} \mathrm{L}_{6}\right]^{\mathrm{m}+\mathrm{m} \cdot \mathrm{w}}$ with $\mathrm{L}^{-} \mathrm{H}_{2} \mathrm{O}$ or $\mathrm{CN}^{-}$ built from a $\left\{\operatorname{Re}_{6} \mathrm{Se}_{8}\right\}$ core formed by six $\mathrm{Re}^{\mathrm{mI}}$ atoms linked through metal-metal bonds. The supramolecular connector is the $\gamma$-CD resulting from the condensation of 8 glucopyranose units. Colour code: purple polyhedron: $\mathrm{WO}_{6}$ unit, grey polyhedron $=\mathrm{PO}_{4}$ unit, green sphere $=\mathrm{Re}$, orange sphere $=\mathrm{Se}$, grey sphere $=$ apical ligand $\left(\mathrm{CN}-\right.$ or $\left.\mathrm{H}_{2} \mathrm{O}\right)$.

Herein, we report on the crystal engineering of novel supramolecular CLUSPOM solids obtained from aqueous mixtures containing $\gamma-\mathrm{CD}$, Dawson anion $\left[\mathrm{P}_{2} \mathrm{~W}_{18} \mathrm{O}_{62}\right]^{6-}$ and face-capped $\left[\left\{\mathrm{Re}_{6} \mathrm{Se}_{8}\right\} \mathrm{L}_{6}\right]^{\mathrm{m}+/ \mathrm{n}-}$ based cluster units (Figure 1). It is worth noting that, the cluster core $\left\{\mathrm{Re}_{6} \mathrm{Se}_{8}\right\}$ can be derived either as the aqua cationic $\left(\left[\left\{\mathrm{Re}_{6} \mathrm{Se}_{8}\right\}\left(\mathrm{H}_{2} \mathrm{O}\right)_{6}\right]^{2+}\right)$ or as the cyano anionic $\left(\left[\left\{\mathrm{Re}_{6} \mathrm{Se}_{8}\right\}(\mathrm{CN})_{6}\right]^{4-}\right)$ building units. This allows investigations upon the role of attractive and repulsive long-range coulombic forces on the CLUSPOM architectures involving $\gamma-C D$. Moreover the $\left[\left\{\mathrm{Re}_{6} \mathrm{Se}_{8}\right\} \mathrm{L}_{6}\right]^{\mathrm{m}+/ \mathrm{n}-}$ units exhibit the best luminescent properties among the rhenium chalcogenide cluster series making them particularly attractive to prepare innovative multifunctional solids. ${ }^{50}$ Prior to evaluate the role of the $\gamma$-CD in the assembling process, we studied the co-crystallization of $\left[\mathrm{P}_{2} \mathrm{~W}_{18} \mathrm{O}_{62}\right]^{6-}$ (noted $\left.\left\{\mathbf{P}_{\mathbf{2}} \mathbf{W}_{\mathbf{1 8}}\right\}\right)$ and $\left[\left\{\mathrm{Re}_{6} \mathrm{Se}_{8}\right\}\left(\mathrm{H}_{2} \mathrm{O}\right)_{6}\right]^{2+}$ (noted $\left\{\mathbf{R e}_{\mathbf{6}}{ }^{\mathbf{c a}}\right\}$ ). This chemical system leads to the isolation of an original CLUSPOM material where the polymetallic units are packed following the NiAs structural arrangement. Then, we show that the presence of $\gamma$-CD, modifies the crystal formation process producing a hierarchical organization 
wherein two cationic clusters sandwiched a POM unit through two distinct $\gamma$-CDs acting as ditopic linker. Using the anionic $\left[\left\{\operatorname{Re}_{6} \mathrm{Se}_{8}\right\}(\mathrm{CN})_{6}\right]^{4-}$ species (noted $\left\{\mathbf{R e}_{6}{ }^{\mathbf{a n}}\right\}$ ) instead of the cationic derivative, another supramolecular CLUSPOM solid was also isolated, highlighting that $\gamma$-CD is even able to maintain inter-cluster supramolecular interactions despite non favorable repulsive anion-anion coulombic forces. Finally, we investigate the pre-aggregation processes occurring in aqueous media by multinuclear 1D NMR, DOSY NMR and small-angle x-ray scattering (SAXS) techniques.

\section{EXPERIMENTAL SECTION}

\section{Synthesis}

The compounds described herein were synthesized from aqueous mixtures of $\gamma$-CD $\left(\mathrm{C}_{48} \mathrm{H}_{80} \mathrm{O}_{40}, \quad\right.$ TCI, $\left.\quad 99 \%\right), \quad \mathrm{K}_{6}\left[\mathrm{P}_{2} \mathrm{~W}_{18} \mathrm{O}_{62}\right] \cdot 19 \mathrm{H}_{2} \mathrm{O}, \quad \mathrm{K}_{4}\left[\left\{\mathrm{Re}_{6} \mathrm{Se}_{8}\right\}(\mathrm{CN})_{6}\right], \quad$ and $\mathrm{K}_{4}\left[\left\{\mathrm{Re}_{6} \mathrm{Se}_{s}\right\}(\mathrm{OH})_{6}\right] \cdot 8 \mathrm{H}_{2} \mathrm{O}$. Dawson-type polyoxometalate and $\left\{\mathrm{Re}_{6} \mathrm{Se}_{8}\right\}$ based clusters were synthesized as described in literature. .15s $^{\text {s.5 }}$

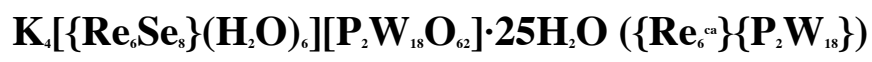

$\mathrm{K}_{4}\left[\left\{\mathrm{Re}_{6} \mathrm{Se}_{8}\right\}(\mathrm{OH})_{6}\right] \cdot 8 \mathrm{H}_{2} \mathrm{O}(50 \mathrm{mg}, 0.028 \mathrm{mmol})$ was dissolved in $2 \mathrm{~mL}$ of $2 \mathrm{M} \mathrm{H}_{2} \mathrm{SO}_{4}$. In parallel $\mathrm{K}_{6}\left[\mathrm{P}_{2} \mathrm{~W}_{18} \mathrm{O}_{62}\right] \cdot 19 \mathrm{H}_{2} \mathrm{O}(140 \mathrm{mg}, 0.028 \mathrm{mmol})$ were dissolved in $2 \mathrm{~mL}$ of water. Then, the resulting solutions were mixed and left to stay on the air. After 5 days, hexagonal crystals of $\left\{\mathbf{R e}_{6}{ }^{\mathrm{c}}\right\}\left\{\mathbf{P}_{2} \mathbf{W}_{\mathrm{is}}\right\}$ were formed and separated from the solution, washed with cold water and dried in air. Yield 0.13 g $(70 \%)$ based on rhenium cluster. EDS shows Re : Se $: \mathrm{K}: \mathrm{P}: \mathrm{W}$ ratio $=6.8: 7.8: 3.8: 18$. TGA revealed a weight loss of about $8.2 \%$ from 25 to $250{ }^{\circ} \mathrm{C}$ (the calculated weight loss of 31 $\mathrm{H}_{2} \mathrm{O}$ is $\left.8.17 \%\right)$.

$\left\{\left[\left\{\mathrm{Re}_{\mathrm{s}} \mathrm{Se}_{\mathrm{s}}\right\}\left(\mathrm{H}_{2} \mathrm{O}\right)_{6}\right] @ \gamma-\mathrm{CD}\right\}\left(\mathrm{NO}_{s}\right)_{2} \cdot \mathbf{1 0 H _ { 2 }} \mathrm{O}\left(\left\{\mathrm{Re}_{\mathrm{c}}{ }_{\mathrm{ac}} \mathrm{a} @ \mathrm{CD}\right)\right.$

$\mathrm{K}_{4}\left[\left\{\mathrm{Re}_{s} \mathrm{Se}_{s}\right\}(\mathrm{OH})_{6}\right] \cdot 8 \mathrm{H}_{2} \mathrm{O}(0.584 \mathrm{~g} ; 0.27 \mathrm{mmol})$ was dissolved in $20 \mathrm{~mL}$ of water, after that $0.5 \mathrm{M}$ $\mathrm{HNO}_{3}$ was added drop wise under stirring until $\mathrm{pH}$ reached 1.5 producing a clear yellow solution. 
$0.704 \mathrm{~g}(0.54 \mathrm{mmol})$ of solid $\gamma$-CD was added directly to this solution under stirring. After dissolution of the macrocyclic cavitand the reaction mixture was allowed to slowly evaporate in air to leave a very small volume of a concentrated solution. When the solution was concentrated, the product started to decompose, therefore, the complex was isolated only as several crystals. Yield: a few crystals. EDS shows Re $:$ Se ratio $=6.0: 8.2$ and confirms the absence of $\mathrm{K}$.

$\mathrm{K}_{2}\left[\left\{\operatorname{Re}_{6} \mathrm{Se}_{8}\right\}\left(\mathrm{H}_{2} \mathrm{O}\right)_{6}\right]_{2}\left\{\left[\mathbf{P}_{2} \mathbf{W}_{18} \mathrm{O}_{62}\right] @ 2 \gamma-\mathrm{CD}\right\} \cdot 42 \mathrm{H}_{2} \mathrm{O}\left(\left\{\operatorname{Re}_{6}^{\mathrm{c}}\right\}_{2}\left\{\mathbf{P}_{2} \mathbf{W}_{18}\right\} @ 2 \mathrm{CD}\right)$

$\mathrm{K}_{4}\left[\left\{\mathrm{Re}_{6} \mathrm{Se}_{8}\right\}(\mathrm{OH})_{6}\right] \cdot 8 \mathrm{H}_{2} \mathrm{O}(0.088 \mathrm{~g}, 0.04 \mathrm{mmol})$ was dissolved in $2 \mathrm{~mL}$ of $2 \mathrm{M} \mathrm{H}_{2} \mathrm{SO}_{4}$. $\mathrm{K}_{6}\left[\mathrm{P}_{2} \mathrm{~W}_{18} \mathrm{O}_{62}\right] \cdot 19 \mathrm{H}_{2} \mathrm{O}(0.1 \mathrm{~g}, 0.02 \mathrm{mmol})$ and $\gamma-\mathrm{CD}(0.057 \mathrm{~g}, 0.04 \mathrm{mmol})$ were dissolved in $1.5 \mathrm{~mL}$ of water. The resulting solutions were mixed and left to stay on the air. After 12 hours, crystalline compound $\left\{\boldsymbol{R e}_{6}^{c a}\right\}_{2}\left\{\mathbf{P}_{2} \mathbf{W}_{18}\right\} @ 2 C D$ were formed and separated from the solution, washed with cold water and dried in air. Yield $0.164 \mathrm{~g}(70 \%)$ based on cluster complex. Anal. Calcd for $\mathrm{C}_{96} \mathrm{H}_{268} \mathrm{~K}_{2} \mathrm{O}_{196} \mathrm{P}_{2} \mathrm{Re}_{12} \mathrm{Se}_{16} \mathrm{~W}_{18}: \mathrm{C}, 9.99 ; \mathrm{H}, 2.34$. Found: C, 10.0; H, 2.4. EDS shows Re : Se : K : P : W ratio $=12: 16.0: 2.2: 2.1: 18.0$. TGA revealed a weight loss of about $6.4 \%$ from 50 to $110{ }^{\circ} \mathrm{C}$ (the calculated weight loss of $42 \mathrm{H}_{2} \mathrm{O}$ is $6.4 \%$ ).

\section{$\mathbf{K}_{10}\left\{\left[\left\{\operatorname{Re}_{6} \operatorname{Se}_{8}\right\}(C N)_{6}\right] @ 2 \gamma-\operatorname{CD}\right\}\left[\mathbf{P}_{2} \mathbf{W}_{18} \mathbf{O}_{62}\right] \cdot 33 H_{2} O\left(\left\{\operatorname{Re}_{6}{ }^{a n}\right\} @ 2 \operatorname{CD}\left\{\mathbf{P}_{2} \mathbf{W}_{18}\right\}\right)$.}

$\mathrm{K}_{4}\left[\left\{\mathrm{Re}_{6} \mathrm{Se}_{8}\right\}(\mathrm{CN})_{6}\right](0.129 \mathrm{~g}, 0.062 \mathrm{mmol})$ was dissolved in $1 \mathrm{~mL}$ of water. $\mathrm{K}_{6}\left[\mathrm{P}_{2} \mathrm{~W}_{18} \mathrm{O}_{62}\right] \cdot 19 \mathrm{H}_{2} \mathrm{O}$ $(0.3 \mathrm{~g}, 0.062 \mathrm{mmol})$ and $\gamma-\mathrm{CD}(0.174 \mathrm{~g}, 0.124 \mathrm{mmol})$ were dissolved in $3 \mathrm{~mL}$ of water. The resulting solutions were mixed and left to stay on the air. During the slow evaporation of the solution, crystals of $\left\{\mathbf{R e}_{6}{ }^{a n}\right\} @ \mathbf{2 C D}\left\{\mathbf{P}_{2} \mathbf{W}_{18}\right\}$ were formed after one day, which were separated from the solution, washed with cold water and dried in air. Yield $0.454 \mathrm{~g}$ (74\%) based on cluster complex. Anal. Calcd for $\mathrm{C}_{102} \mathrm{H}_{206} \mathrm{~K}_{10} \mathrm{~N}_{6} \mathrm{O}_{175} \mathrm{P}_{2} \mathrm{Re}_{6} \mathrm{Se}_{8} \mathrm{~W}_{18}$ : C, 12.41; H, 2.31; N, 0.85. Found: C, 12.6; $\mathrm{H}, 2.4 ; \mathrm{N}, 0.9$. EDS shows $\mathrm{Re}: \mathrm{Se}: \mathrm{K}: \mathrm{P}: \mathrm{W}$ ratio $=6: 7.9: 9.8: 2.1: 18.0$. TGA revealed a weight loss of about $6.0 \%$ from 50 to $150{ }^{\circ} \mathrm{C}$ (the calculated weight loss of $33 \mathrm{H}_{2} \mathrm{O}$ is $6.0 \%$ ).

\section{Single Crystal X-ray Diffraction}

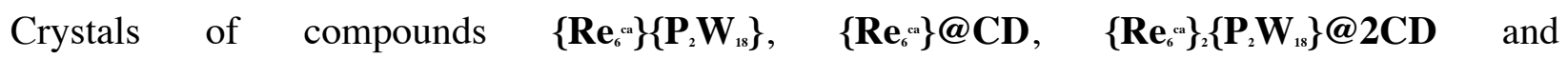
$\left\{\mathbf{R e}_{6}{ }^{\text {an }}\right\} @ \mathbf{C D}\left\{\mathbf{P}_{2} \mathbf{W}_{18}\right\}$, were selected under polarizing optical microscope and glued in paratone oil to prevent any loss of crystallization water. X-ray intensity data were collected at low 
temperature $(\mathrm{T}=200(2) \mathrm{K})$ on Bruker D8 VENTURE diffractometer equipped with a PHOTON 100 CMOS bidimensional detector using a high brilliance I $\mu$ S microfocus X-ray MoK $\alpha$ monochromatized radiation $(\lambda=0.71073 \AA)$. Data reduction was accomplished using SAINT V7.53a. The substantial redundancy in data allowed a semi-empirical absorption correction (SADABS V2.10) to be applied, on the basis of multiple measurements of equivalent reflections. Using Olex2,,$^{, 4}$ the structure was solved with the ShelXT ${ }^{55}$ structure solution program using Intrinsic Phasing and refined with the ShelXL ${ }^{56}$ refinement package using Least Squares minimization. The remaining non-hydrogen atoms were located from Fourier differences and were refined with anisotropic thermal parameters. Positions of the hydrogen atoms of $\gamma$-CD were refined in the calculated positions. In the compound $\left\{\mathbf{R e}^{\mathrm{an}}\right\} @ \mathbf{2} \mathbf{C D}\left\{\mathbf{P}_{2} \mathbf{W}_{\mathrm{s}}\right\}$, numerous free water molecules $\left(\mathrm{H}_{2} \mathrm{O}\right)$ as well as the counter cations $\left(\mathrm{K}^{+}\right)$located inside the voids are disordered. Thereby the contribution of solvent-electron density was removed using the SQUEEZE routine in PLATON, producing a set of solvent-free diffraction intensities. A disorder of the rhenium clusters on two positions (occupancy 50\% / 50\%) is observed in $\left\{\mathbf{R e}_{6}{ }^{a n}\right\} @ \mathbf{C} \mathbf{C D}\left\{\mathbf{P}_{2} \mathbf{W}_{18}\right\}$ (details are given in the Supporting Information, see Figure S2). Crystallographic data for single-crystal Xray diffraction studies are summarized in Tables S1-4 and the bond lengths of the inorganic building blocks are reported in Tables S5-11. CIF files can be obtained free of charge from the Cambridge Crystallographic Data Centre via https://www.ccdc.cam.ac.uk. Deposit number: $\left\{\mathbf{R e}_{6}{ }_{\mathrm{ca}}\right\}\left\{\mathbf{P}_{2} \mathbf{W}_{18}\right\}: 1995746,\left\{\mathbf{R e}_{6}^{\mathrm{ca}}\right\} @ \mathbf{C D}: 1995747,\left\{\mathbf{R e}_{6}^{\mathrm{ca}}\right\}_{2}\left\{\mathbf{P}_{2} \mathbf{W}_{18}\right\} @ 2 \mathbf{C D}: 1995749$, and $\left\{\boldsymbol{R e}_{6}{ }^{a n}\right\} @ 2 \mathbf{C D}\left\{\mathbf{P}_{2} \mathbf{W}_{18}\right\}: 1995748$.

\section{NMR studies.}

All solution NMR spectra were measured in $\mathrm{D}_{2} \mathrm{O}$ at $27^{\circ} \mathrm{C}$. ${ }^{\mathrm{H}} \mathrm{H},{ }^{31} \mathrm{P}$ and ${ }^{7} \mathrm{Se}$ NMR spectra were obtained on a Bruker Avance 400 spectrometer at Larmor frequencies of 400.1, 162.0, and 77.3 $\mathrm{MHz}$ respectively, while ${ }^{183} \mathrm{~W}$ NMR on a Bruker Avance 500 spectrometer at Larmor frequency of 20.8 MHz. Translational diffusion measurements were performed using Bruker's "ledbpgs2s" stimulated echo DOSY pulse sequence including bipolar and spoil gradients. Apparent diffusion coefficients were obtained using an adapted algorithm based on the inverse Laplace transform 
and maximum entropy. Chemical shifts are reported relative to standards: $\mathrm{Me}_{4} \mathrm{Si}\left(\mathrm{CDCl}_{3}, 1\right.$ wt. \%) for ' $\mathrm{H}, \mathrm{H}_{3} \mathrm{PO}_{4}$ for ${ }^{31} \mathrm{P}, \mathrm{Me}_{2} \mathrm{Se}$ for ${ }^{77} \mathrm{Se}$, and $\mathrm{Na}_{2} \mathrm{WO}_{4}\left(\mathrm{D}_{2} \mathrm{O}, 1 \mathrm{M}\right)$ for ${ }^{183} \mathrm{~W} .{ }^{.7}$

\section{Small Angle X-ray Scattering.}

SAXS experiments were performed at the SWING beamline of the SOLEIL synchrotron (SaintAubin, France). Measurements were carried out using a fixed energy of $12 \mathrm{keV}$. Samples were inserted in glass capillaries $(\varnothing=1.5 \mathrm{~mm})$, the exposition time was fixed to $1000 \mathrm{~ms}$ and scattering patterns were recorded on EIGER-4M (Dectris) camera. Simulated scattering curves of polymetallic unit as in their inclusion complexes with CD were generated using SolX ${ }^{, 8}$ utilizing structural files (xyz).

\section{Infrared spectroscopy.}

Fourier Transform Infrared (FT-IR) spectra were recorded on a 6700 FT-IR Nicolet spectrophotometer, using diamond ATR technique. The spectra were recorded on non-diluted compounds in the range $400-4000 \mathrm{~cm}^{-1}$. The IR spectra are provided in Supporting Information (see Figure S5-6).

\section{Energy-Dispersive X-ray Spectroscopy.}

EDS measurements were performed using a SEM-FEG (Scanning Electron Microscope enhanced by a Field Emission Gun) equipment (JSM 7001-F, Jeol). The measurements were acquired with a SDD XMax $50 \mathrm{~mm}^{2}$ detector and the Aztec (Oxford) system working at $15 \mathrm{kV}$ and $10 \mathrm{~mm}$ distance. The quantification $(\mathrm{P}, \mathrm{W}, \mathrm{Se}, \mathrm{Re}, \mathrm{K}, \mathrm{Na})$ is realized with the standard library provided by the constructor using $\mathrm{L}_{\alpha}$ lines.

Thermogravimetric analysis (TGA).

Analysis was performed on Mettler Toledo TGA/DSC 1, STARe System apparatus under oxygen flow $\left(50 \mathrm{~mL} \mathrm{~min}^{-1}\right)$ at a heating rate of $5^{\circ} \mathrm{C} \min ^{-1}$ up to $600^{\circ} \mathrm{C}$.

\section{RESULTS AND DISCUSSION}

\section{Formation of 'CLUSPOM salt'}


Before any investigation in the presence of $\gamma$-CD, we attempted the co-crystallization of Dawson type POM with cationic aqua complex $\left[\left\{\operatorname{Re}_{6} \mathrm{Se}_{8}\right\}\left(\mathrm{H}_{2} \mathrm{O}\right)_{6}\right]^{2+}$. Evaporation of an equimolar mixture of $\left[\mathrm{P}_{2} \mathrm{~W}_{18} \mathrm{O}_{62}\right]^{6-}$ and $\left[\left\{\mathrm{Re}_{6} \mathrm{Se}_{8}\right\}\left(\mathrm{H}_{2} \mathrm{O}\right)_{6}\right]^{2+}$ in weakly acidic condition yields large yellow hexagonal crystals of $\mathrm{K}_{4}\left[\left\{\mathrm{Re}_{6} \mathrm{Se}_{8}\right\}\left(\mathrm{H}_{2} \mathrm{O}\right)_{6}\right]\left[\mathrm{P}_{2} \mathrm{~W}_{18} \mathrm{O}_{62}\right] \cdot 25 \mathrm{H}_{2} \mathrm{O} \quad\left(\left\{\mathbf{R e}_{6}^{c a}\right\}\left\{\mathbf{P}_{2} \mathbf{W}_{18}\right\}\right)$. X-ray structural analysis reveals a 'CLUSPOM salt' crystallizing in the centrosymmetric space group $P 6_{3} / \mathrm{m}$. Briefly, this compound consists of an assembly of Dawson type anion and $\mathrm{Re}_{6}$ cluster cation generating the nickeline structure type (NiAs) often observed in transition-metal chalcogenides and pnictogenides..$^{59}$ In such an arrangement, the gravity center of the $\left[\mathrm{P}_{2} \mathrm{~W}_{18} \mathrm{O}_{62}\right]^{6-}$ ion lies on the As site while the $\left[\left\{\operatorname{Re}_{6} \mathrm{Se}_{8}\right\}\left(\mathrm{H}_{2} \mathrm{O}\right)_{6}\right]^{2+}$ cation is located on the Ni site (Figure 2). Structural analysis reveals that the geometrical parameters of the polymetallic units correspond to those usually observed in their salts. The packing of the polymetallic units can be described as a hexagonal packing of the $\left[\left\{\operatorname{Re}_{6} \mathrm{Se}_{8}\right\}\left(\mathrm{H}_{2} \mathrm{O}\right)_{6}\right]^{2+}$ cation, forming symmetrically equivalent layer along the sixfold axis. The $\left[\mathrm{P}_{2} \mathrm{~W}_{18} \mathrm{O}_{62}\right]^{6}$ units are located between these layers of octahedral clusters and occupy alternately one half of the trigonal prismatic sites. Consequently, the polyoxometalate unit is surrounded by six cationic clusters in the corners of a trigonal prism, while the cluster is surrounded by six Dawson anions forming an octahedron. The distance between the gravity center of cationic and anionic unit is about $10.7 \AA$ and the shortest distance between these two molecular units is $3.01 \AA$ corresponding to a very weak hydrogen bond between the terminal aqua ligand of the rhenium cluster and the terminal oxygen atom of the polyoxometalate (Re$\left.\mathrm{OH}_{2} \bullet \bullet \mathrm{O}=\mathrm{W}\right)$. Herein, the contribution of the short-range interaction between the surfaces of the building blocks appears limited. Therefore, we conclude that the 3D organization is mainly driven by long-range coulombic interactions between large $\left[\mathrm{P}_{2} \mathrm{~W}_{18} \mathrm{O}_{62}\right]^{6-}$ anions and $\left[\left\{\mathrm{Re}_{6} \mathrm{Se}_{8}\right\}\left(\mathrm{H}_{2} \mathrm{O}\right)_{6}\right]^{2+}$ cations and by the intrinsic high symmetry of the polymetallic building blocks, which is $D_{3 h}$ and $O_{h}$ for $\left[\mathrm{P}_{2} \mathrm{~W}_{18} \mathrm{O}_{62}\right]^{6-}$ and $\left[\left\{\mathrm{Re}_{6} \mathrm{Se}_{8}\right\}\left(\mathrm{H}_{2} \mathrm{O}\right)_{6}\right]^{2+}$, respectively. The charge balance of $\left\{\mathbf{R e}_{6}{ }_{6}\right\}\left\{\mathbf{P}_{2} \mathbf{W}_{18}\right\}$ is compensated by four potassium cations (confirmed by EDS analysis). Crystallographic data refinement indicates that disordered $\mathrm{K}^{+}$ions with $33 \%$ occupancy (more 
details in the Supporting Information), are surrounded by free water molecules, terminal aqua ligands of the rhenium cluster or oxygen atoms of the POM unit.

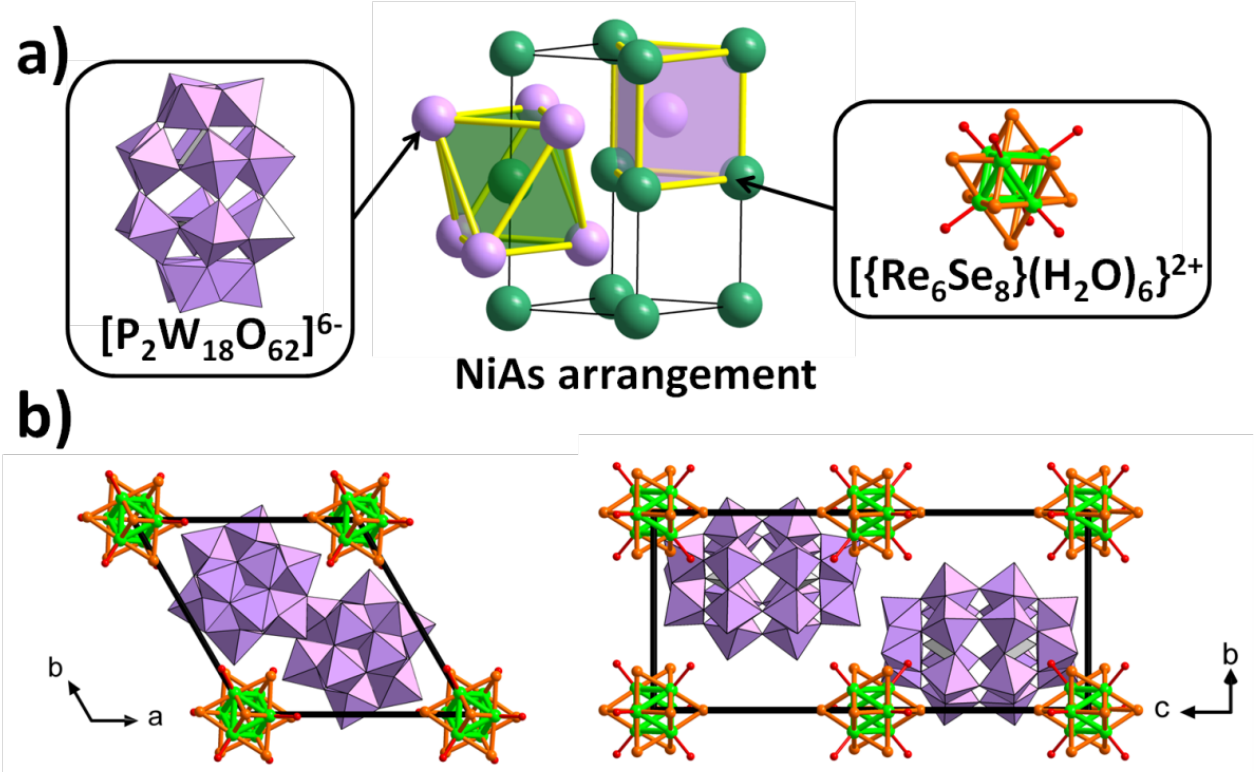

Figure 2. a) Illustration of the structural arrangement derived from NiAs structure where the Dawson anion and the cationic octahedral cluster lie on the $\mathrm{As}^{3-}$ and $\mathrm{Ni}^{3+}$ positions, respectively. b) Projections of the crystal structure $\left\{\mathbf{R e}_{6}{ }_{c}^{a}\right\}\left\{\mathbf{P}_{2} \mathbf{W}_{18}\right\}$ along the 001 (left) and 100 (right) directions. The water molecules and free potassium atoms are omitted for clarity.

\section{Binary systems involving $\gamma-C D$}

Predicting the self-assembly process between CD and two distinct building blocks involves first to identify the rules governing the binary systems in the presence of $\gamma-\mathrm{CD} .^{41}$

In our previous reports on the binary aqueous systems $\left[\mathrm{P}_{2} \mathrm{~W}_{18} \mathrm{O}_{62}\right]^{6 / \gamma}-\mathrm{CD}$ and $\left[\left\{\mathrm{Re}_{6} \mathrm{Se}_{8}\right\}(\mathrm{CN})_{6}\right]^{4} / \gamma-$ $\mathrm{CD}$, we have shown that $\gamma$-CD binds both these polymetallic units with similar association constant (about $10^{3} \mathrm{M}^{-1}$ ), but interacts with different rims (Figure 3). ${ }^{4+15}$ The Dawson anion assembles through the smaller $\gamma$-CD face giving variable stoichiometry in the solid-state (from 1 to $3 \mathrm{CDs}$ per POM unit) (Figure 3b) $)^{4,48}$ Oppositely, the $\left[\left\{\mathrm{Re}_{6} \mathrm{Se}_{8}\right\}(\mathrm{CN})_{6}\right]^{+}$anion interplays with $\gamma$ CD through the larger rim of the macrocycle, forming 1:2 inclusion complex (Figure 3c) ${ }^{45}$ The 
binary system $\left[\left\{\operatorname{Re}_{6} \mathrm{Se}_{8}\right\}\left(\mathrm{H}_{2} \mathrm{O}\right)_{6}\right]^{2+} / \gamma-\mathrm{CD}$ has been also investigated, revealing very weak binding constant according to 'H NMR data, however no structural data was reported. ${ }^{\circ 0}$ The stability of inclusion complexes involving $\left\{\mathrm{Re}_{6} \mathrm{Se}_{8}\right\}$ clusters and $\gamma$-CD strongly depends on both the chaotropicity of the cluster and the host-guest size-matching. ${ }_{\cdot}^{4,47}$ The cationic cluster $\left(\mathrm{V}=350 \AA^{3}\right)$ is probably too small to fit well with $\gamma$-CD cavity, in contrast to the bigger anionic cluster $(\mathrm{V}=$ $\left.420 \AA^{3}\right)$. To fill the lack of knowledge about the arrangement of $\left[\left\{\operatorname{Re}_{6} \mathrm{Se}_{8}\right\}\left(\mathrm{H}_{2} \mathrm{O}\right)_{6}\right]^{2+}$ and $\gamma-\mathrm{CD}$ in the solid-state, we successfully crystallized, by evaporation from a solution with both components, the 1:1 supramolecular adduct $\left\{\left[\left\{\operatorname{Re}_{6} \mathrm{Se}_{8}\right\}\left(\mathrm{H}_{2} \mathrm{O}\right)_{6}\right] @ \gamma-\mathrm{CD}\right\}\left(\mathrm{NO}_{3}\right)_{2} \bullet 10 \mathrm{H}_{2} \mathrm{O}$, notated as $\left\{\boldsymbol{R e}_{6}{ }^{a}\right\} @ \mathbf{C D}$. This compound is isostructural to that previously reported with the sulphur containing cluster $\left[\left\{\mathrm{Re}_{6} \mathrm{~S}_{8}\right\}\left(\mathrm{H}_{2} \mathrm{O}\right)_{6}\right]^{2+}{ }^{20}$ Complete structural description is included in supplementary information (Fig. S3 and S4). In short, the crystal structure consists of a 1:1 hostguest complex, where the cationic cluster is entrapped in the centre of the larger rim of the tori host (Figure 3d). The closest host-guest distance (about $3.2 \AA$ ) is observed between four water molecules of the cluster unit and four hydroxo groups located on the secondary face of the macrocyclic host. 

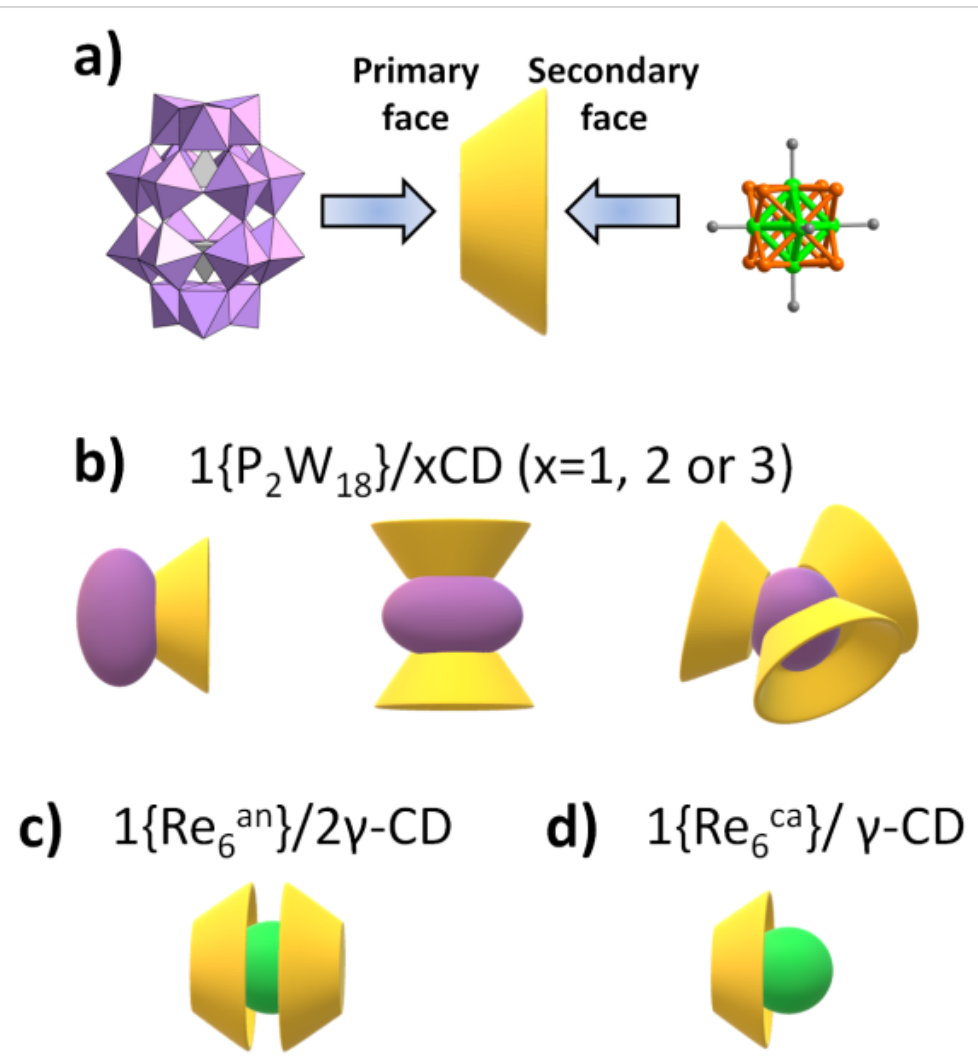

Figure 3. a) Selective binding of the $\gamma$-CD (yellow) with the metallic units, especially the Dawson anion (purple oval) and $\mathrm{Re}_{6}$ based clusters (green sphere). b) Schematic illustration of the different supramolecular adduct previously observed in the solid-state for $\left[\mathrm{P}_{2} \mathrm{~W}_{18} \mathrm{O}_{62}\right]^{6-}(\mathrm{b})$, $\left.\left[\operatorname{Re}_{6} \mathrm{Se}_{8}\right\}(\mathrm{CN})_{6}\right]^{4+}(\mathrm{c})$ and $\left[\left\{\mathrm{Re}_{6} \mathrm{Se}_{8}\right\}\left(\mathrm{H}_{2} \mathrm{O}\right)_{6}\right]^{2+}(\mathrm{d})$.

\section{Ternary systems involving the cationic cluster}

The results obtained on binary systems give fundamental insights to construct, in a predictive way, novel CLUSPOM materials based on the combination of the three components namely the $\gamma-\mathrm{CD}$, the cationic octahedral cluster, and the Dawson-type POM. Actually, because $\left[\mathrm{P}_{2} \mathrm{~W}_{18} \mathrm{O}_{62}\right]^{6-}$ and $\left[\left\{\operatorname{Re}_{6} \mathrm{Se}_{8}\right\}\left(\mathrm{H}_{2} \mathrm{O}\right)_{6}\right]^{2+}$ interact with the different $\gamma$-CD faces, the macrocycle is expected to act as a ditopic supramolecular linker wherein the secondary face nests the cluster and the POM is inserted in the primary face. 


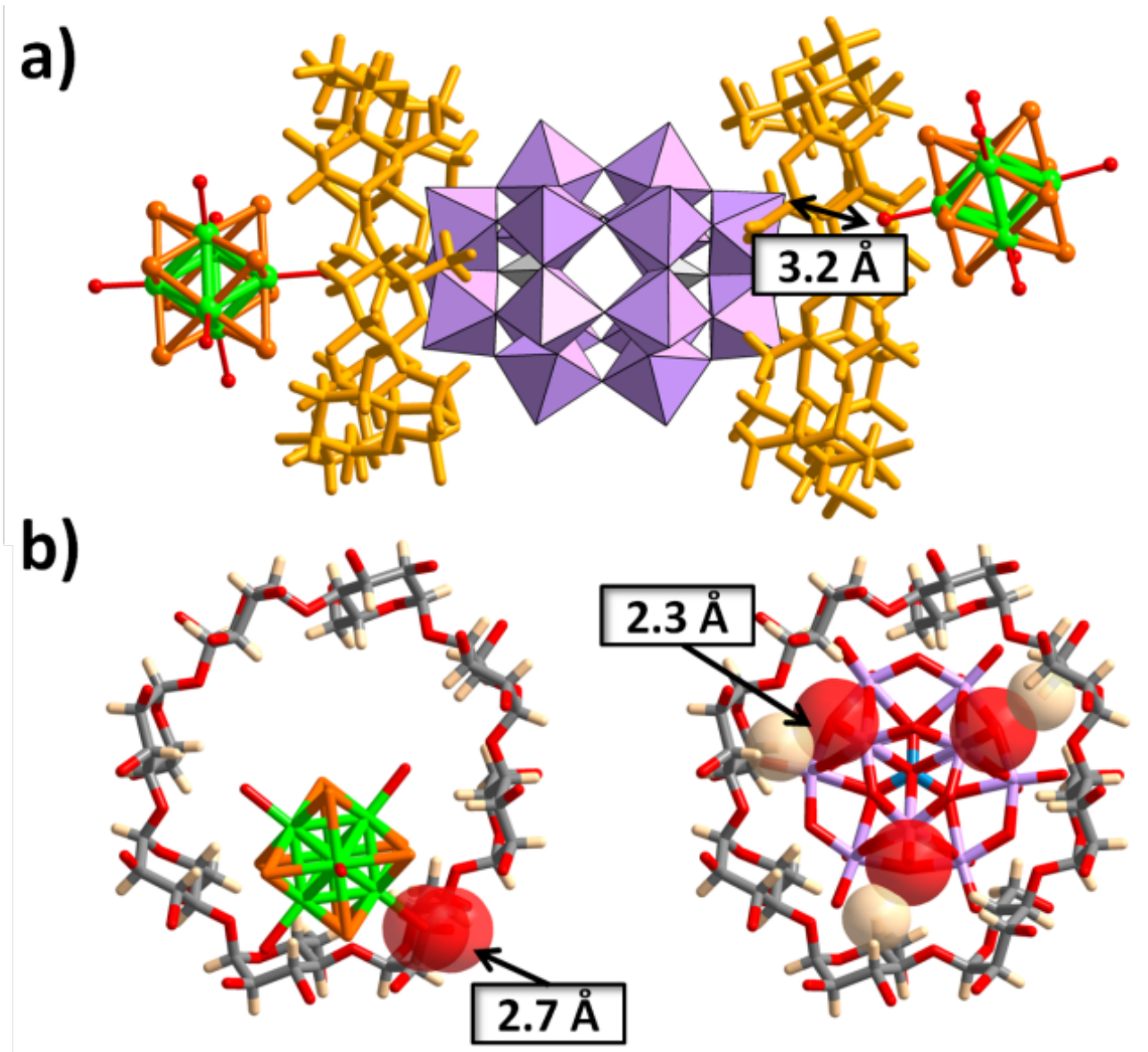

Figure 4. a) View of the three-component supramolecular adduct showing a central Dawsontype polyoxometalate decorated by two $\gamma$-CDs interacting with the primary face while the secondary face of these macrocyclic host interact with two cationic rhenium clusters. The shortest distance between the inorganic entities is about $3.2 \AA$. b) Top plan views of the strongest interactions between the cyclodextrin and the polymetallic units (left with the cluster; right with the POM).

Mixing cationic rhenium cluster (obtained by dissolving of $\mathrm{K}_{4}\left[\left\{\mathrm{Re}_{6} \mathrm{Se}_{8}\right\}(\mathrm{OH})_{6}\right] \bullet 8 \mathrm{H}_{2} \mathrm{O}$ in an acidic medium) in $2 \mathrm{M}$ sulphuric acid with an aqueous solution containing $\gamma$-CD, in the molar ratios of $\left\{\operatorname{Re}_{6}^{c a}\right\}:\left\{\mathrm{P}_{2} \mathrm{~W}_{18}\right\}: \gamma-\mathrm{CD}:=2: 1: 2$ (fast precipitation of tiny crystals) and 1:1:2 (formation of high quality crystals) leads to crystallization $\left\{\mathbf{R e}_{6}{ }_{6}\right\}_{2}\left\{\mathbf{P}_{2} \mathbf{W}_{18}\right\} @ \mathbf{2 C D}$. SCXRD analysis indicates that the unit cell (space group P1) contains two Dawson type anions, four cationic clusters and four $\gamma$-CDs. This supramolecular hierarchically built CLUSPOM solid can be viewed as a packing of two crystallographically independent bamboo-shaped fragments built from the following cluster-macrocycle-POM-macrocycle-cluster sequence where $\gamma$-CD acts as ditopic linker (Figure 4a). Within this motif, POMs and clusters interplay with the same binding mode 
than those observed in the binary systems. In fact, each $\gamma-\mathrm{CD}$ interacts with the $\left[\mathrm{P}_{2} \mathrm{~W}_{18} \mathrm{O}_{62}\right]^{6-}$ through the primary face, while the secondary face entrap $\left[\left\{\operatorname{Re}_{6} \mathrm{Se}_{8}\right\}\left(\mathrm{H}_{2} \mathrm{O}\right)_{6}\right]^{2+}$. The supramolecular adduct is stabilized by six $[\mathrm{C}-\mathrm{H} \bullet \bullet \bullet \mathrm{O}=\mathrm{W}]$ interactions $\left(\mathrm{d}_{\mathrm{c-H}-\mathrm{H} \cdot \mathrm{O}=\mathrm{W}} \approx 2.3 \AA\right.$ ) between inner protons of $\gamma$-CD (labelled H5) and the terminal oxygen atoms of the two capping units of the Dawson anion (Figure 3b). In addition, short contacts between H6 protons of $\gamma-\mathrm{CD}$ and "equatorial" terminal

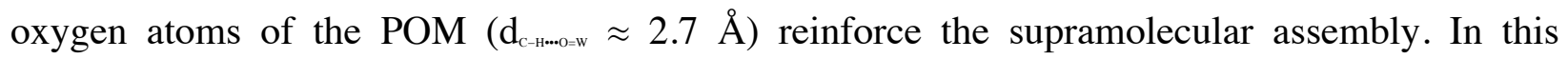
supramolecular adduct $\left\{\left[\mathrm{P}_{2} \mathrm{~W}_{18} \mathrm{O}_{62}\right] @ 2 \gamma-\mathrm{CD}\right\}^{6-}$, the $\gamma$-CDs are perpendicular to the three-fold axis of the POMs and its cavity embeds the two trimeric units $\left\{\mathrm{W}_{3} \mathrm{O}_{13}\right\}$ of the Dawson anion. This feature shows some analogy with the inclusion complex prepared with the Keggin type polyoxometalate $\left[\mathrm{PMo}_{12} \mathrm{O}_{40}\right]^{3-}$ in which the trimeric metalate unit $\left\{\mathrm{Mo}_{3} \mathrm{O}_{13}\right\}$ are also enclosed into the host cavities. ${ }^{42}$ Interestingly, the disposition of $\gamma$-CD around the Dawson unit in $\left\{\boldsymbol{R e}_{6}{ }^{\mathrm{c}}\right\}_{2}\left\{\mathbf{P}_{2} \mathbf{W}_{18}\right\} @ 2 C D$ differs from those previously observed in absence of rhenium clusters, in which the supramolecular complexation occurs on the larger side of POM.4 This observation highlights the versatility of the binding between $\left[\mathrm{P}_{2} \mathrm{~W}_{18} \mathrm{O}_{62}\right]^{6-}$ and $\mathrm{CD}$.

Each remaining $\gamma$-CD faces of $\left\{\left[\mathrm{P}_{2} \mathrm{~W}_{18} \mathrm{O}_{62}\right] @ 2 \gamma-\mathrm{CD}\right\}^{6-}$ nests a cationic $\left[\left\{\mathrm{Re}_{6} \mathrm{Se}_{8}\right\}\left(\mathrm{H}_{2} \mathrm{O}\right)_{6}\right]^{2+}$ cluster (Figure 4a). This inorganic entity deviates strongly from the center of the macrocycle contrarily to the structural motif observed without the POM (see structural description of $\left\{\mathbf{R e}_{6}{ }^{{ }^{a}}\right\} @ \mathbf{C D}$ in SI). The structural analysis indicates hydrogen bonding between one apical water molecule of the octahedral cluster and a hydroxyl group of the secondary face $\left(\mathrm{d}_{\text {о-ннннове }} \approx 2.7 \AA\right.$ ) (Figure $\left.4 \mathbf{b}\right)$. In addition, short contacts are also depicted between the inner selenide ligand and two hydrogen atoms of the $\gamma$-CD cavity (labeled H3). Hence, $\gamma$-CD acts as a ditopic supramolecular ligands, allowing the hierarchical association of cationic $\mathrm{Re}_{6}$ clusters and Dawson anion which are distanced by $3.2 \AA$, like in the CLUSPOM salt $\left\{\mathbf{R e}_{6}^{\mathrm{ca}}\right\}\left\{\mathbf{P}_{2} \mathbf{W}_{18}\right\}$.

The 3D organization is rather challenging to depict. As we have previously mentioned, two crystallographically independent $\left\{\left[\left\{\mathrm{Re}_{6} \mathrm{Se}_{8}\right\}\left(\mathrm{H}_{2} \mathrm{O}\right)_{6}\right]_{2} \cdot\left[\mathrm{P}_{2} \mathrm{~W}_{18} \mathrm{O}_{62}\right] @ 2 \gamma-\mathrm{CD}\right\}^{2-}$ motifs constitute the unit cell (Figure 5a). These supramolecular three-component assemblies are associated together through a set of weak interactions (hydrogen bonds and short contacts) involving the inorganic 
units from one motif and the cyclodextrin from the other (Figure 5c). In brief, hydrogen bonds between the terminal water molecules and hydroxo group of primary $\gamma$-CD face $\left(\mathrm{d}_{\text {о-ншнногеве }} \approx 2.7 \AA\right)$, as well as various short contacts between oxygen atoms of the POM and hydrogen atoms located on the external wall of $\gamma-\mathrm{CD}\left(\mathrm{d}_{\text {c-Hwo-w }} \approx 2.5-2.8 \AA\right)$ contribute to the $3 \mathrm{D}$ cohesion. Moreover, the supramolecular architecture is reinforced by hydrogen bonds between hydroxo groups (secondary face) of the two distinct cyclodextrins belonging to crystallographically equivalent bamboo fragments (Figure 5b). It results a packing of nano-sized rods aligned along [-111] (Figure S1). The electroneutrality of $\left\{\mathbf{R e}_{6}{ }^{\mathrm{c}}\right\}_{2}\left\{\mathbf{P}_{2} \mathbf{W}_{18}\right\} @ 2 C D$ is ensured by two potassium cations per $\left\{\left[\left\{\operatorname{Re}_{6} \mathrm{Se}_{8}\right\}\left(\mathrm{H}_{2} \mathrm{O}\right)_{6}\right]_{2} \cdot\left[\mathrm{P}_{2} \mathrm{~W}_{18} \mathrm{O}_{62}\right] @ 2 \gamma-\mathrm{CD}\right\}^{2-}$ assembly (confirmed by EDS analysis).

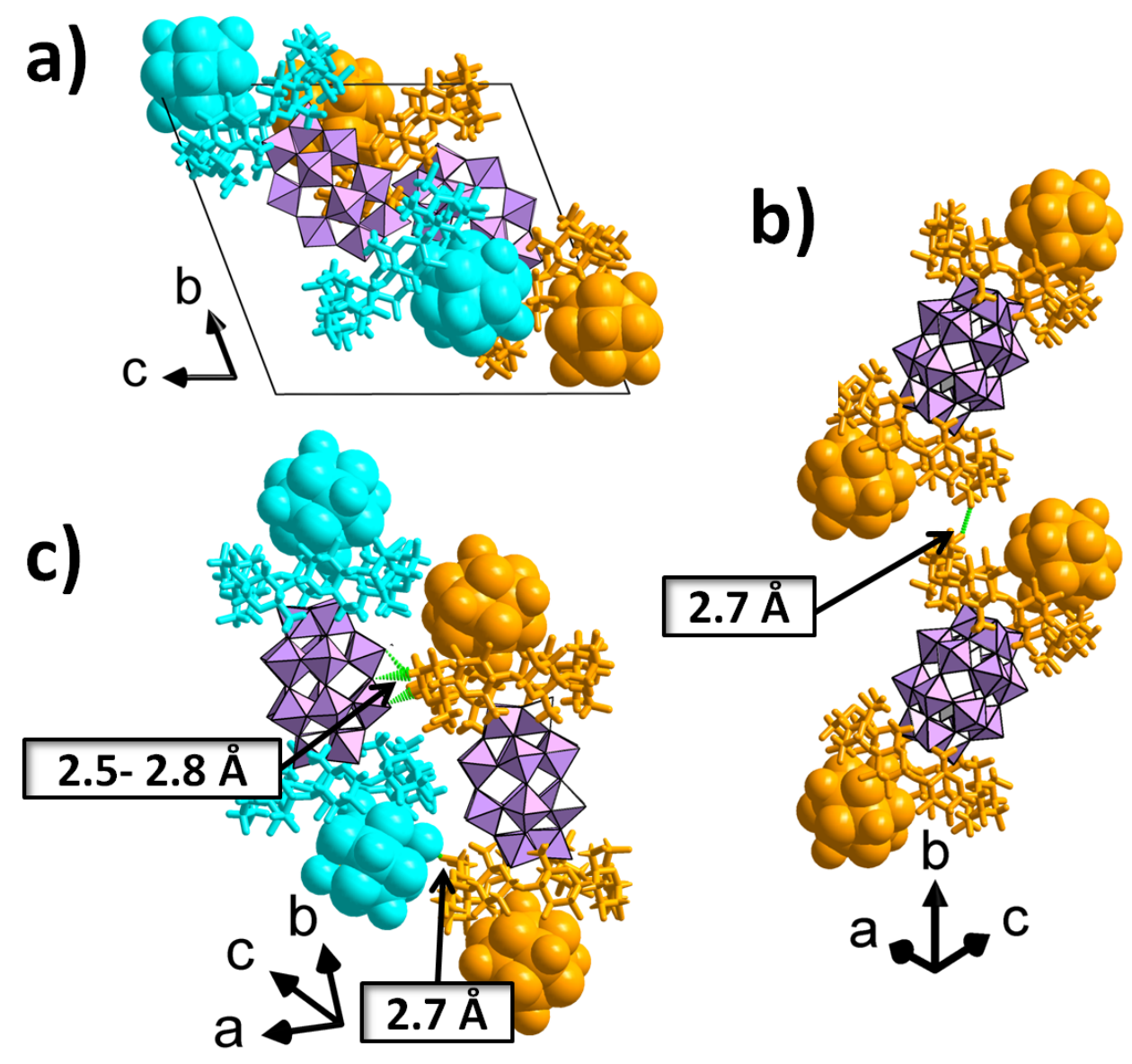

Figure 5. a) Projection of the unit cell along $a$ axis showing the two crystallographically independent bamboo fragments observed in $\left\{\operatorname{Re}_{6}^{c^{a}}\right\}_{2}\left\{\mathrm{P}_{2} \mathrm{~W}_{18}\right\} @ 2 \mathrm{CD}$. The water molecules and free potassium atoms are omitted for clarity. b) Each independent bamboo fragments are linked to each other by a set of hydrogen bonds between two adjacent $\gamma$-CDs, generating zig-zag chain along $b$ axis. c) View of the supramolecular interactions (hydrogen bonds and short $\mathrm{d}_{\text {c-nwo-w }}$ 
contacts) between two crystallographically independent bamboo fragments. The green dashed lines indicate short contacts and hydrogen bonds.

In a previous study dealing with the CLUSPOM $\left[\mathrm{P}_{2} \mathrm{~W}_{18} \mathrm{O}_{62}\right]^{6 / \gamma}-\mathrm{CD} /\left[\left\{\mathrm{Ta}_{6} \mathrm{Br}_{12}\right\}\left(\mathrm{H}_{2} \mathrm{O}\right)_{6}\right]^{2+}$, we isolated an infinite chain showing a periodic -cluster-macrocycle-POM-macrocycle- sequence where each $\left\{\left[\mathrm{P}_{2} \mathrm{~W}_{18} \mathrm{O}_{62}\right] @ 2 \gamma-\mathrm{CD}\right\}^{6}$ supramolecular motif links two others by the tantalum cluster closely embedded into two $\gamma$-CDs from distinct $\left\{\left[\mathrm{P}_{2} \mathrm{~W}_{18} \mathrm{O}_{62}\right] @ 2 \gamma-\mathrm{CD}\right\}^{6}$ assemblies. Oppositely, the molecular nature of $\left\{\mathbf{R e}_{6}^{c_{a}}\right\}_{2}\left\{\mathbf{P}_{2} \mathbf{W}_{18}\right\} @ 2 C D$ assemblies would indicate that the cationic $\left\{\operatorname{Re}_{6} \mathrm{Se}_{8}\right\}$ cluster acts as a "stopper". This difference is explained from the distinct supramolecular behavior of clusters in presence of $\gamma$-CD. In fact, investigations in solution showed that $\gamma$-CD exhibits very high affinity to edge-bridged $\left[\left\{\mathrm{Ta}_{6} \mathrm{Br}_{12}\right\}\left(\mathrm{H}_{2} \mathrm{O}\right)_{6}\right]^{2+}$, generating a strong 1:2 inclusion complex, whereas $\gamma$-CD showed a very weak affinity to $\left[\left\{\mathrm{Re}_{6} \mathrm{Se}_{8}\right\}\left(\mathrm{H}_{2} \mathrm{O}\right)_{6}\right]^{2+}$ leading to a fragile $1: 1$ adduct. . $^{4.60}$ These two examples highlight that weak supramolecular forces can control the aggregation between inorganic building blocks having opposite charges into the hierarchical CLUSPOM architecture which can be anticipated by considering the properties of the binary systems $i . e . \gamma$ $\mathrm{CD}$ and polymetallic units.

\section{Ternary systems involving the anionic cluster}

The promising results of using cyclodextrin to organize the ionic packing of preformed polynuclear inorganic entities in the solid-state encourage us to push the limits of this approach by assembling two different anionic building blocks, such as $\left[\left\{\mathrm{Re}_{6} \mathrm{Se}_{8}\right\}(\mathrm{CN})_{6}\right]^{+}$and $\left[\mathrm{P}_{2} \mathrm{~W}_{18} \mathrm{O}_{62}\right]^{\sigma}$. In such systems long-range electrostatic repulsion and short-range supramolecular forces should compete within the aggregation process while cyclodextrin would act as a POM-cluster connector. 


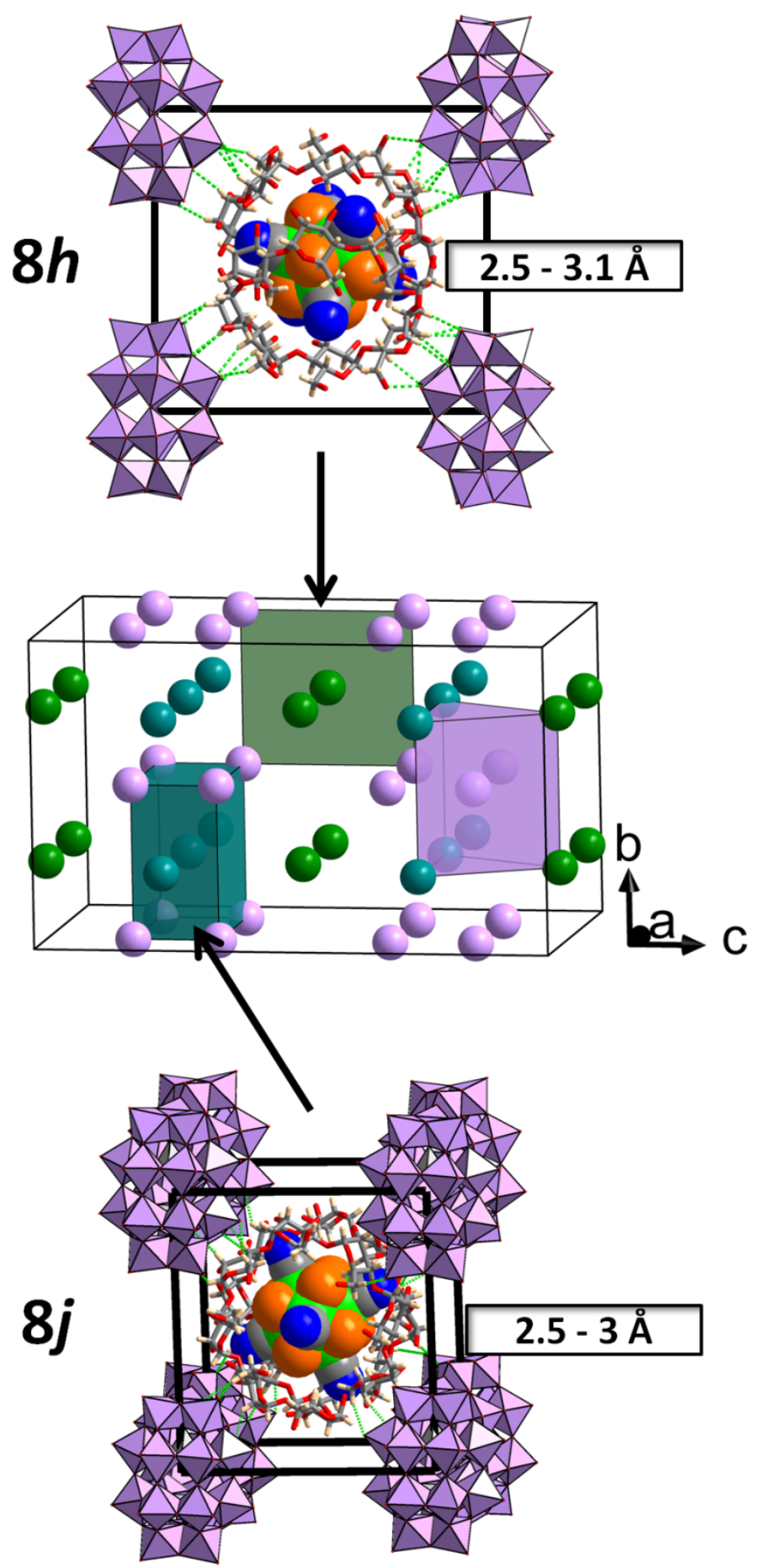

Figure 6. View of the structural arrangement in the compound $\left\{\mathbf{R e}^{\mathrm{a}}{ }^{\mathrm{a}}\right\} @ \mathbf{2} \mathbf{C D}\left\{\mathbf{P}_{2} \mathbf{W}_{\mathrm{s}}\right\}$ built from $\left[\mathrm{P}_{2} \mathrm{~W}_{18} \mathrm{O}_{62}\right]^{6-}$ and inclusion complexes $\left\{\left[\left\{\mathrm{Re}_{6} \mathrm{Se}_{8}\right\}(\mathrm{CN})_{6}\right] @ 2 \gamma-\mathrm{CD}\right\}^{+}$located at the Wyckoff position $8 j$ and $8 h$. The water molecules and free potassium atoms are omitted for clarity. The green dashed lines indicate short contacts and hydrogen bonds between Dawson-type POM and $\gamma-C D$. 
From this three components system, we successfully isolated a crystalline solid containing both anionic $\left\{\mathrm{Re}_{6} \mathrm{Se}_{s}\right\}$-based cluster and the polyoxometalate unit. This compound notated $\left\{\mathbf{R e}_{6}{ }^{a n}\right\} @ 2 \mathbf{C D}\left\{\mathbf{P}_{2} \mathbf{W}_{18}\right\}$ was isolated by evaporation of an aqueous mixture of $\left[\left\{\operatorname{Re}_{\mathrm{s}} \mathrm{Se}_{\mathrm{s}}\right\}(\mathrm{CN})_{\mathrm{c}}\right]^{4}$, $\left[\mathrm{P}_{2} \mathrm{~W}_{18} \mathrm{O}_{6]}\right]^{-}$and $\gamma-\mathrm{CD}$ in the molar ratio cluster:POM: $\gamma-\mathrm{CD}=1: 1: 2$. This CLUSPOM solid crystallizes in F222 space group. The unit cell volume is quite large $\left(\mathrm{V} \approx 108020 \AA^{3}\right)$ and the asymmetric unit consists of one polyoxometalate unit and two inclusion complexes $\left\{\left[\left\{\mathrm{Re}_{s} \mathrm{Se}_{s}\right\}(\mathrm{CN})_{6}\right] @ 2 \gamma-\mathrm{CD}\right\}^{+}$centred at the Wyckoff position $8 j(0,1 / 4,1 / 4)$ and $8 h(1 / 4,1 / 4,0)$ (Figure 6). The inclusion complexes $\left\{\left[\left\{\operatorname{Re}_{\diamond} \mathrm{Se}_{\mathrm{s}}\right\}(\mathrm{CN})_{6}\right] @ 2 \gamma-\mathrm{CD}\right\}^{+}$exhibit the same structural arrangement as those observed in absence of the polyoxometalate. ${ }^{45}$ In brief, the octahedral cluster disordered over two positions (50\%/50\%), is closely embedded into two $\gamma$-CDs facing their wider rim. The equatorial cyano groups interact through hydrogen bonds with the hydroxo groups of the secondary face, giving $\mathrm{N} \bullet \bullet \mathrm{O}$ distances in the 2.8-3.0 A range. The exterior surface of the supramolecular adduct $\left\{\left[\left\{\operatorname{Re}_{\mathrm{s}} \mathrm{Se}_{\mathrm{s}}\right\}(\mathrm{CN})_{\mathrm{c}}\right] @ 2 \gamma-\mathrm{CD}\right\}^{+}$centred at the Wyckoff position $8 h$ interacts with oxygen atoms of four Dawson anions in a square geometry through a set of short contacts and hydrogen bonds (Figure 6). The adduct $\left\{\left[\left\{\mathrm{Re}_{6} \mathrm{Se}_{\mathrm{s}}\right\}(\mathrm{CN})_{6}\right] @ 2 \gamma-\mathrm{CD}\right\}^{\star}$ located at the Wyckoff position $8 j$ shows a different arrangement of the neighbouring polyoxometalate units. Actually, this inclusion complex is located within a square prism defined by eight Dawson anions which interact through weak bonds with the external surface of the $\gamma$-CD (Figure 6). In such a structural organization, each Dawson anion is located at the centre of trigonal-prism where the shortest distance between the two inorganic units is about $5.5 \AA$. Ten remaining $\mathrm{K}^{+}$ cations per polyoxometalate unit (confirmed by EDS analysis) are required for charge balancing. They are distributed with water molecules within the large voids (36\% of cell volume) generated by the crystal packing.

It should be worth mentioning that in $\left\{\mathbf{R e}_{6}{ }^{\mathrm{m}}\right\} @ \mathbf{2} \mathbf{C D}\left\{\mathbf{P}_{2} \mathbf{W}_{\mathrm{is}}\right\}$, the $\left[\mathrm{P}_{2} \mathrm{~W}_{\mathrm{s}} \mathrm{O}_{6}\right]^{\circ}$ does not form any inclusion complex with $\gamma-\mathrm{CD}$ and interacts preferably only with its outer surface. Thus, the situation observed here differs from those observed with the supramolecular CLUSPOM edifices built with cationic clusters such as $\left[\left\{\mathrm{Ta}_{6} \mathrm{Br}_{12}\right\}\left(\mathrm{H}_{2} \mathrm{O}\right)_{6}\right]^{2+}$ or $\left[\left\{\mathrm{Re}_{6} \mathrm{Se}_{8}\right\}\left(\mathrm{H}_{2} \mathrm{O}\right)_{6}\right]^{2+}$. Therefore, we conclude 
that these differences arise from equilibrated balance between the different attractive forces that operate within the aggregation process. They result from the short-range supramolecular interactions which govern the nature of the host-guest arrangement, and from long-range coulombic repulsions that increase the shortest distances between the anionic POM and cluster species. Nevertheless, using $\gamma$-CD permits isolation of supramolecular CLUSPOM solids built from distinct anionic building blocks. To the best of our knowledge, only gigantic ring-shaped POM species were previously identified as able to aggregate with anionic polymetallic units. 4.616-64 $^{46}$

\section{Characterizing the solution phase by multi-nuclear NMR and Small-Angle X- ray Scattering}

As aqueous mixtures of $\left\{\mathrm{Re}_{6} \mathrm{Se}_{8}\right\}$ based clusters, taken either in anionic or cationic form, $\gamma$-CD, and Dawson type polyoxometalate promote three-component systems in the solid-state, it could be postulated that pre-aggregation process should take place in solution. In such context, multinuclear NMR $\left({ }^{1} \mathrm{H},{ }^{31} \mathrm{P},{ }^{77} \mathrm{Se},{ }^{183} \mathrm{~W}\right)$ experiments were first performed to describe in details the local interactions between the three components. For a complete insight about possible aggregation processes, we carried out DOSY NMR and small-angle x-ray scattering (SAXS), which is a powerful technique to observe self-assembly involving inorganic polynuclear entities in solution..$^{65}$

$\left[\mathrm{P}_{2} \mathrm{~W}_{18} \mathrm{O}_{62}\right]^{6} / \gamma-\mathrm{CD} /\left[\left\{\mathrm{Re}_{6} \mathrm{Se}_{8}\right\}\left(\mathrm{H}_{2} \mathrm{O}\right)_{6}\right]^{2+}$ system.

For this system, the following cluster: $\gamma-\mathrm{CD}:$ POM molar ratios $1: 2: 1,0: 2: 1,1: 2: 0$ were studied by NMR spectroscopy, as well as each component separately ([POM] and $[$ cluster $]=10 \mathrm{mM} ;[\gamma-\mathrm{CD}]=20 \mathrm{mM})$. Note that increasing the cluster amount up to 2 equivalents (2:2:1), leads rapidly to the precipitation of $\left\{\operatorname{Re}_{\mathbf{6}}{ }^{\mathrm{ca}}\right\}_{\mathbf{2}}\left\{\mathbf{P}_{\mathbf{2}} \mathbf{W}_{\mathbf{1 8}}\right\} @ \mathbf{2 C D}$. According to ${ }^{1} \mathrm{H}$ NMR spectra, $\gamma$-CD signals are strongly influenced by POM units (strong shift of H6). However the $\gamma$-CD signal is almost not affected by the cationic 
cluster (Figure 7a). Similarly, the addition of cationic clusters to a solution of POM and $\gamma$-CD provokes only tiny changes, characterized by a small chemical shift of H6 and H3 $(0.02 \mathrm{ppm})$ and a weak broadening of proton signals. The ${ }^{31} \mathrm{P}$ and ${ }^{183} \mathrm{~W}$ NMR spectra (Figures S7 and S8), show the signatures of the Dawson POM $\left[\mathrm{P}_{2} \mathrm{~W}_{18} \mathrm{O}_{62}\right]^{6-}$. While ${ }^{31} \mathrm{P}$ NMR exhibited only very small changes presumably because phosphorus nuclei are protected inside the internal POM cavity, ${ }^{183} \mathrm{~W}$ NMR spectra are mostly affected by the presence of the $\mathrm{CD}$ and the effect of cluster appears insignificant. From the cluster side, the ${ }^{77}$ Se spectra revealed very weak interaction with the $\gamma$-CD as ca. $1 \mathrm{ppm}$ downfield shift is observed, whereas the POM does not affect significantly the cluster spectrum (Figure S9). Thus, in this system, the interactions of POM with $\gamma$-CD seem to be predominant and only a very weak effect of the cluster is observed. At first sight, this suggests the formation of $\left[\left[\mathrm{P}_{2} \mathrm{~W}_{18} \mathrm{O}_{62}\right] @ \mathrm{x} \gamma-\mathrm{CD}\right\}^{6-}$ assembly as main species. 

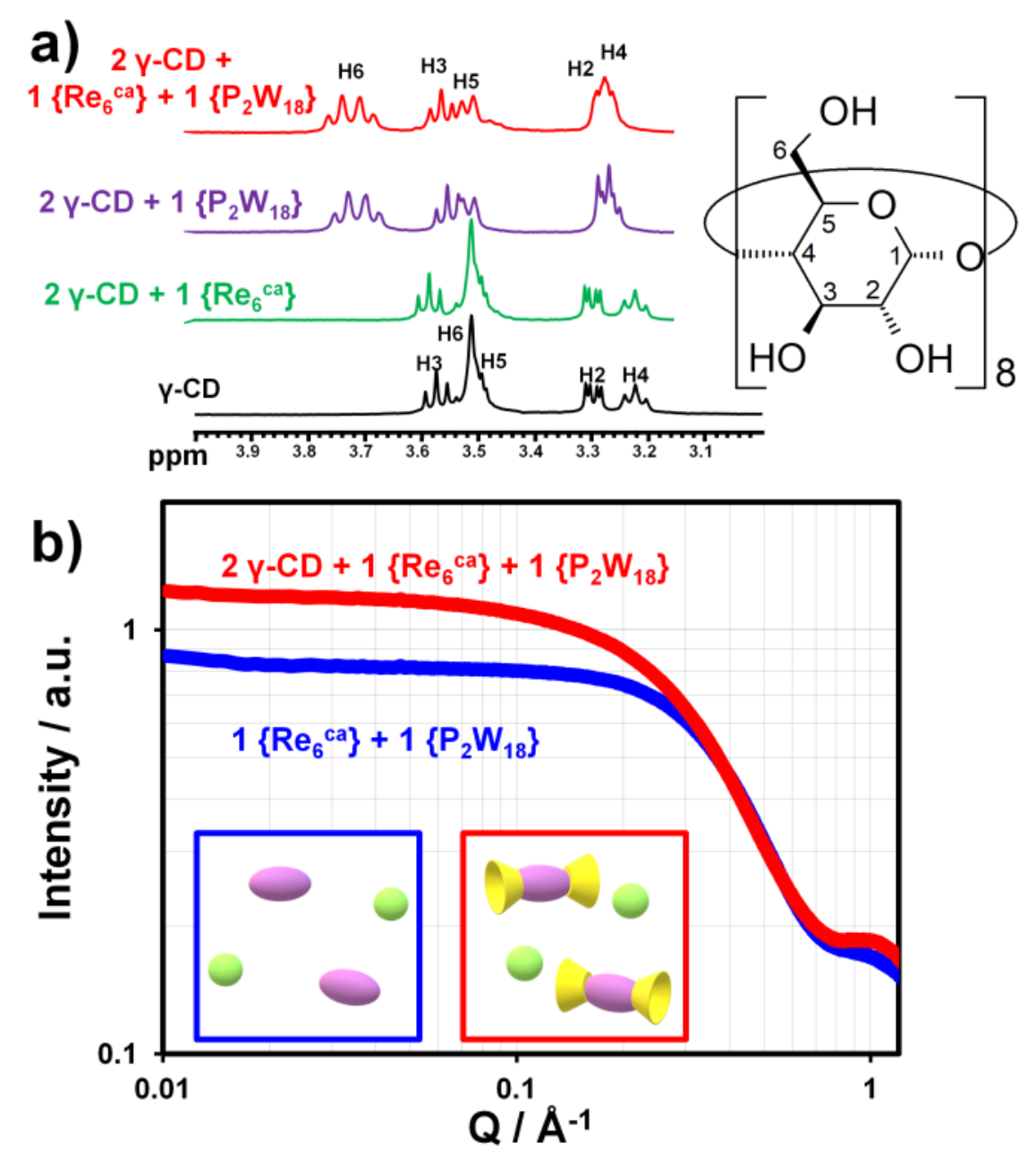

Figure 7. a) 'H NMR spectra of $\gamma-\mathrm{CD}([\gamma-\mathrm{CD}]=20 \mathrm{mM})$ in acidified $\mathrm{D}_{2} \mathrm{O}$ for different mixtures containing $\left[\left\{\mathrm{Re}_{6} \mathrm{Se}_{8}\right\}\left(\mathrm{H}_{2} \mathrm{O}\right)_{6}\right]^{2+}$ or $\left[\mathrm{P}_{2} \mathrm{~W}_{18} \mathrm{O}_{62}\right]^{6}$. b) Comparison of the $\log (\mathrm{q})-\log (\mathrm{I}(\mathrm{q}))$ scattering curves of the $\left.\left[\mathrm{P}_{2} \mathrm{~W}_{18} \mathrm{O}_{62}\right]^{6 /[} /\left[\mathrm{Re}_{6} \mathrm{Se}_{8}\right\}\left(\mathrm{H}_{2} \mathrm{O}\right)_{6}\right]^{2+}$ system (blue curve) with the $\left[\mathrm{P}_{2} \mathrm{~W}_{18} \mathrm{O}_{62}\right]^{6 /} / \gamma$ $\mathrm{CD} /\left[\left\{\mathrm{Re}_{6} \mathrm{Se}_{8}\right\}\left(\mathrm{H}_{2} \mathrm{O}\right)_{6}\right]^{2+}$ system (red curve). The concentration of $\left[\left\{\mathrm{Re}_{6} \mathrm{Se}_{8}\right\}\left(\mathrm{H}_{2} \mathrm{O}\right)_{6}\right]^{2+}$ and $\left[\mathrm{P}_{2} \mathrm{~W}_{18} \mathrm{O}_{62}\right]^{6-}$ is $10 \mathrm{mM}$. SAXS and NMR studies have been carried out in diluted sulfuric acid (1M). All solutions were equilibrated for $24 \mathrm{~h}$ prior to NMR or SAXS measurements.

The NMR conclusions are supported by SAXS investigations performed in similar condition (same concentration of reactants). Figure $7 \mathrm{~b}$ shows X-ray scattering curves of a cluster and polyoxometalate containing solution with or without $\gamma$-CD. It should be mentioned that nonaggregated cyclodextrin is almost silent in SAXS analysis. For both scattering curves, a plateau is observed in low q region, indicating the absence of inter-particle interferences which means that no large aggregates are formed. The SAXS curves were fitted in the Guinier region to extract the average $\mathrm{Rg}$ value (radius of gyration, the root-mean-square distance of all the 
electrons from the gravity centre of the particles). In absence of $\gamma$-CD, the $\operatorname{Rg}$ value is about $4 \AA$; this is in agreement with a solution containing Dawson type anions (theoretical $\operatorname{Rg}=4.5 \AA$ ) and cationic $\left\{\operatorname{Re}_{6} \mathrm{Se}_{8}\right\}$ based clusters (theoretical $\mathrm{Rg}=2.5 \AA$ ). Interestingly, addition of $\gamma$-CD increases the $\operatorname{Rg}$ value (4.8 $\AA$ ), meaning an expansion of the particle size as expected from the binding of POM unit by $\gamma-\mathrm{CD}$. Another significant difference between the SAXS curves, concerns the relative $\mathrm{I}(0)$ value which is about 0.86 and 1.23 in absence and presence of $\gamma-\mathrm{CD}$, respectively, involving a $\mathrm{I}(0) \mathrm{CD} / \mathrm{I}(0)$ noCD ratio of 1.43 . This value should be compared to the theoretical $\mathrm{I}(0)$ ratio determined for the following mixtures: i) 1 free cluster +1 free $\gamma-\mathrm{CD}+1$ POM@1 $\gamma$-CD (1.2), ii) 1 free cluster + POM@2 $\gamma-C D(1.4)$ and iii) POM@2 $\gamma$-CD@ cluster (2.2) (details are provided in the Supporting Information, see Table S12 and Figure S14). Consequently, SAXS and NMR investigations conclude that the solution is mainly dominated by supramolecular aggregates involving mainly the POM unit and $\gamma$-CD macrocycle. Such a supramolecular assembly is observed in the crystal structure of $\left\{\mathbf{R e}_{6}^{\mathrm{ca}}\right\}_{2}\left\{\mathbf{P}_{2} \mathbf{W}_{18}\right\} @ \mathbf{2 C D}$, in which the pre-associated anionic motif $\left\{\left[\mathrm{P}_{2} \mathrm{~W}_{18} \mathrm{O}_{62}\right] @ 2 \gamma-\mathrm{CD}\right\}^{\circ}$ is decorated by two cationic clusters.

$$
\left[\underline{\mathrm{P}}_{2} \underline{\mathrm{W}}_{18} \underline{\mathrm{O}}_{62}\right]^{6-} / \gamma-\mathrm{CD} /\left[\left\{\mathrm{Re}_{6} \underline{\mathrm{Se}}_{8}\right\}(\mathrm{CN})_{6}\right]^{4-} \text { system. }
$$

As previously, this study of $\left[\mathrm{P}_{2} \mathrm{~W}_{18} \mathrm{O}_{62}\right]^{6 / \gamma}-\mathrm{CD} /\left[\left\{\mathrm{Re}_{6} \mathrm{Se}_{8}\right\}(\mathrm{CN})_{6}\right]^{-}$system was performed using fixed $\gamma$-CD concentration of $20 \mathrm{mM}$. Thus, according to ${ }^{\prime} \mathrm{H}$ NMR spectra (Figure 8a), the signals of cyclodextrin protons are influenced by both inorganic components and balanced between both $\left[\left\{\mathrm{Re}_{6} \mathrm{Se}_{8}\right\}(\mathrm{CN})_{6}\right]^{4} / \gamma-\mathrm{CD}$ and $\left[\mathrm{P}_{2} \mathrm{~W}_{18} \mathrm{O}_{62}\right]^{6 / \gamma} / \mathrm{CD}$ systems. This suggests that the $\gamma$-CD-based inclusion complexes involving POM or $\left\{\mathrm{Re}_{6} \mathrm{Se}_{8}\right\}$ cluster exist simultaneously in solution. Such a result would be consistent with previous studies showing that the stability constants determined by ITC fall in the same range of magnitude $\left(K=2 \cdot 10^{3}-3 \cdot 10^{3}\right.$ mol. $\left.\mathrm{L}^{-1}\right)$ for both adducts.4.45 Formation of higher aggregates resulting from multi-components cluster-macrocycle-POM based adducts is excluded according to DOSY NMR (see below). Thus, the observed 'H NMR spectrum of the three-component mixture should correspond to a situation of a competition between POM and cluster entities to bind $\gamma-\mathrm{CD}$. The ${ }^{31} \mathrm{P}$ and ${ }^{183} \mathrm{~W}$, and the ${ }^{7}$ Se NMR spectra 
(Figures S10-12) are also consistent with significant interactions between inorganic clusters (POM and rhenium cluster) only in presence of the $\gamma$-CD in solutions.

As observed by NMR, SAXS technique clearly evidences strong interactions of $\left[\left\{\operatorname{Re}_{6} \mathrm{Se}_{8}\right\}(\mathrm{CN})_{6}\right]^{+-}$with the $\gamma$-CD (Figure 8b). In fact, adding CD to aqueous mixture of anionic clusters drastically modifies the scattering curve (increase of scattering intensity and apparition of an oscillation located $\mathrm{q}=0.4 \AA^{-1}$ ). The $\mathrm{Rg}$ values extracted from the fitting of experimental data are 2.2 and $5.3 \AA$ in absence and in presence of $\gamma-C D$, respectively. The experimental $\operatorname{Rg}$ of the $\gamma$-CD containing solution corresponds to an intermediate value between Rg calculated for 1:1 and 1:2 inclusion complexes (4.8 vs $5.7 \AA$ for $1: 1$ and 1:2, respectively, see Figure S15).

SAXS investigation reveals that the solution behaviour of the $\left[\mathrm{P}_{2} \mathrm{~W}_{18} \mathrm{O}_{62}\right]^{6-} / \gamma-$ $\mathrm{CD} /\left[\left\{\mathrm{Re}_{6} \mathrm{Se}_{8}\right\}(\mathrm{CN})_{6}\right]^{4-}$ system differs from the system with the cationic cluster. In fact, SAXS curves exhibit a broad coulombic peaks, characterized by a decrease of the intensity at low q values (Figure 8c), indicating a structuring arising from cluster-cluster repulsions in solution. 

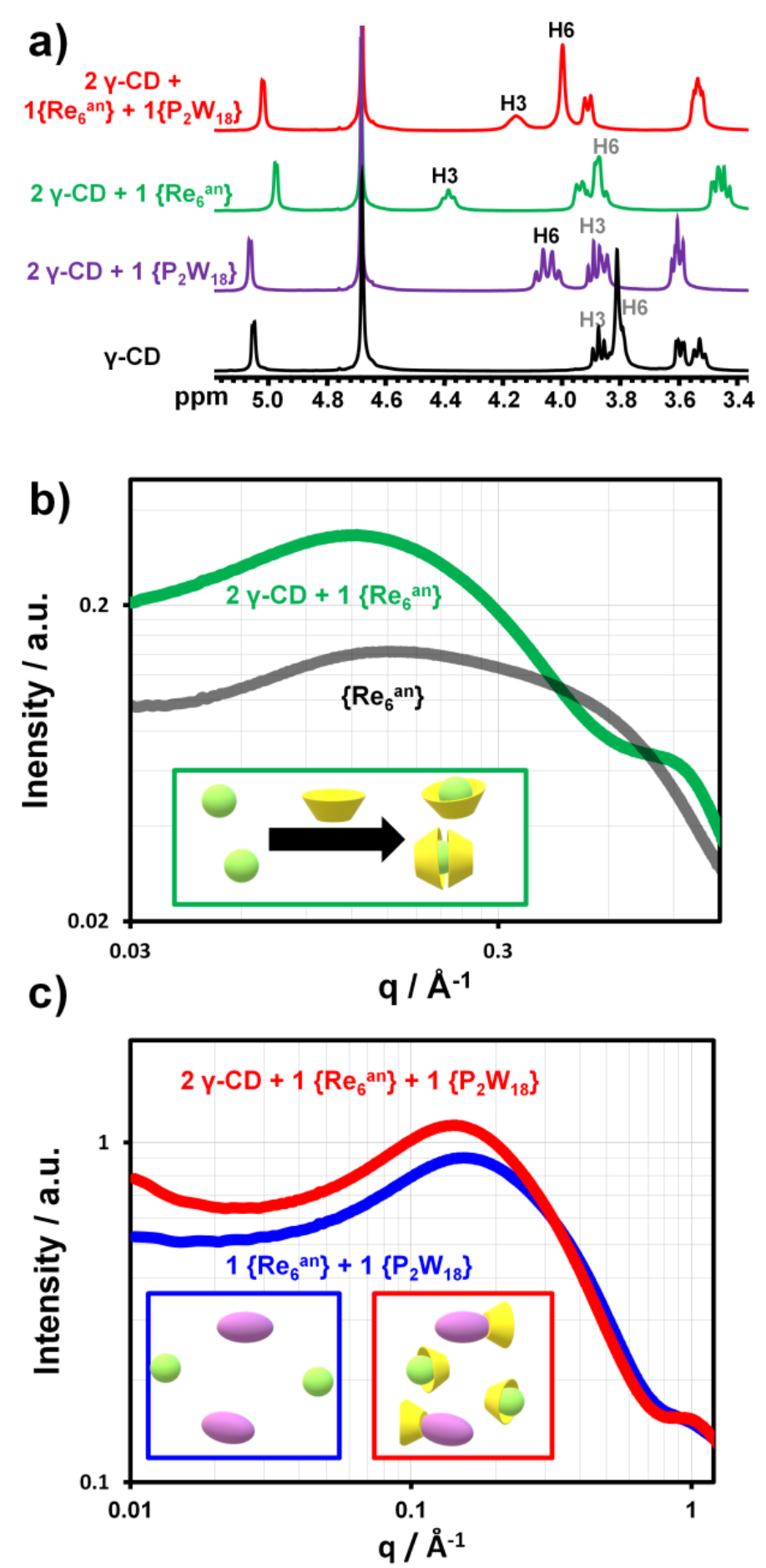

Figure 8 a) ' $\mathrm{H}$ NMR spectra of $\gamma$-CD $([\gamma-C D]=20 \mathrm{mM})$ in $\mathrm{D}_{2} \mathrm{O}$ in presence and absence of $\left[\left\{\mathrm{Re}_{6} \mathrm{Se}_{8}\right\}(\mathrm{CN})_{6}\right]^{+}$and $\left[\mathrm{P}_{2} \mathrm{~W}_{18} \mathrm{O}_{62}\right]^{6}$. b) Comparison of the $\log (\mathrm{q})-\log (\mathrm{I}(\mathrm{q}))$ scattering curves of the rhenium cluster solution with (green curve) and without $\gamma$-CD (grey curve). c) Comparison of the $\log (\mathrm{q})-\log (\mathrm{I}(\mathrm{q}))$ scattering curves of the $\left[\mathrm{P}_{2} \mathrm{~W}_{18} \mathrm{O}_{62}\right]^{6 /[}\left[\left\{\mathrm{Re}_{6} \mathrm{Se}_{8}\right\}(\mathrm{CN})_{6}\right]^{+}$system (blue curve) with the $\left[\mathrm{P}_{2} \mathrm{~W}_{18} \mathrm{O}_{62}\right]^{6} / \gamma-\mathrm{CD} /\left[\left\{\mathrm{Re}_{6} \mathrm{Se}_{8}\right\}(\mathrm{CN})_{6}\right]^{+}$system (red curve). All solutions were equilibrated for $24 \mathrm{~h}$ prior to NMR or SAXS measurements. 
This could be expected since the solution contains only anionic units. Although inter-particle interferences prevent accurate interpretation of the $\mathrm{I}(0)$ increase with the $\gamma$-CD addition, we assume that this indicates mainly the formation of inclusion complexes. This is also supported by Guinier fitting of the SAXS curves showing that adding $\gamma$-CD induces only a slight Rg increase $\left(\operatorname{Rg}^{\mathrm{no}(}(\mathrm{CD})=4.3 \AA\right.$ vs $\left.\operatorname{Rg}^{\left({ }^{(} \mathrm{CD}\right)}=5 \AA\right)$. The SAXS observations coupled with NMR data allow us to conclude that the aqueous $\left[\mathrm{P}_{2} \mathrm{~W}_{18} \mathrm{O}_{62}\right]^{6-} / \gamma-\mathrm{CD} /\left[\left\{\mathrm{Re}_{6} \mathrm{Se}_{8}\right\}(\mathrm{CN})_{6}\right]^{4-}$ system is dominated by inclusion complexes, such as $\left\{\left[\left\{\mathrm{Re}_{6} \mathrm{Se}_{\mathrm{s}}\right\}(\mathrm{CN})_{6}\right] @ \mathrm{x} \gamma-\mathrm{CD}\right\}^{+}$and $\left\{\left[\mathrm{P}_{2} \mathrm{~W}_{18} \mathrm{O}_{62}\right] @ \mathrm{x} \gamma-\mathrm{CD}\right\}^{6-}$, rather than three-component supramolecular aggregates mostly cancelled by repulsive coulombic forces. Interestingly, the evaporation of such aqueous mixtures led to the formation of the crystalline compound $\left\{\mathbf{R e}^{a}{ }^{a n}\right\} \mathbf{2} \mathbf{C D}\left\{\mathbf{P}_{2} \mathbf{W}_{\text {is }}\right\}$ that exhibits exclusively inclusion complexes built from the anionic cluster, $\left\{\left[\left\{\operatorname{Re}_{s} \mathrm{Se}_{s}\right\}(C N)_{6}\right] @ 2 \gamma-C D\right\}^{+}$. The POM unit interacts with the external wall of the CDs that encapsulated the anionic cluster. This situation, which differs from those observed in solution, can be due to the minimization of lattice energy in the solid-state (e.g. limiting the long-range coulombic repulsion).

\section{Diffusion measurements of $\gamma$-CD by DOSY NMR.}

DOSY NMR spectroscopy could provide additional information about interaction of the inorganic clusters with the $\gamma$-CD and their aggregation in solution. Table 1 summarizes the measured diffusion coefficients of $\gamma$-CD in the same solutions studied by SAXS shown in Figures 7 and 8 . The diffusion rate $D$ drops from 235 to $187 \mu \mathrm{m} / \mathrm{s}$ when 0.5 equivalent of $\left[\mathrm{P}_{2} \mathrm{~W}_{18} \mathrm{O}_{62}\right]^{6-}$ is introduced in $20 \mathrm{mM} \gamma-\mathrm{CD}$ solution as a result of significant interaction. Addition of $\left\{\operatorname{Re}_{s} \mathrm{Se}_{\mathrm{s}}\right\}$-based clusters also resulted in decreasing the value of $D$ but in lower extent. Interestingly, in the ternary system in presence of $\left[\mathrm{P}_{2} \mathrm{~W}_{18} \mathrm{O}_{62}\right]^{6-}, D$ decreases as an indication of further interaction of the host molecule but not in the same manner. With the anionic cluster 
$\left[\left\{\operatorname{Re}_{6} \mathrm{Se}_{8}\right\}(\mathrm{CN})_{6}\right]^{4-}$, this decrease is modest and the observed $D 198 \mu \mathrm{m} 2 / \mathrm{s}$ corresponds to an intermediate value between those obtained in binary systems $\gamma-\mathrm{CD} /\left[\mathrm{P}_{2} \mathrm{~W}_{18} \mathrm{O}_{62}\right]^{6-}$ and $\gamma-$ $\mathrm{CD} /\left[\left\{\operatorname{Re}_{6} \mathrm{Se}_{8}\right\}(\mathrm{CN})_{6}\right]^{4}$. This means as concluded previously with SAXS results, the solution is dominated by a coexistence of $\left\{\left[\left\{\operatorname{Re}_{s} \mathrm{Se}_{\mathrm{s}}\right\}(\mathrm{CN})_{6}\right] @ \mathrm{x} \gamma-\mathrm{CD}\right\}^{+}$and $\left\{\left[\mathrm{P}_{2} \mathrm{~W}_{18} \mathrm{O}_{62}\right] @ \mathrm{x} \gamma-\mathrm{CD}\right\}^{6-}$ without further aggregation. However, the situation is different with three component system involving the cationic cluster $\left[\left\{\mathrm{Re}_{6} \mathrm{Se}_{\mathrm{s}}\right\}\left(\mathrm{H}_{2} \mathrm{O}\right)_{6}\right]^{2+}$ where a lower value of $D$ is observed by comparison to the binary systems that could indicate a multicomponent aggregation involving $\gamma$ $\mathrm{CD},\left[\mathrm{P}_{2} \mathrm{~W}_{18} \mathrm{O}_{62}\right]^{6-}$, and $\left[\left\{\mathrm{Re}_{6} \mathrm{Se}_{s}\right\}\left(\mathrm{H}_{2} \mathrm{O}\right)_{6}\right]^{\text {ta }}$. In line with SAXS results, these observations highlight the importance of coulombic interaction to either stimulate POM-cluster association or induce their repulsion.

Table 1. Diffusion coefficients from 'H DOSY NMR of $\gamma$-CD $([C D]=20 \mathrm{mM})$ in $\mathrm{D}_{2} \mathrm{O}$ in presence and absence of $\left[\left\{\operatorname{Re}_{6} \mathrm{Se}_{3}\right\}(\mathrm{CN})_{6}\right]^{+},\left[\left\{\mathrm{Re}_{6} \mathrm{Se}_{3}\right\}\left(\mathrm{H}_{2} \mathrm{O}\right)_{6}\right]^{2+}$ and $\left[\mathrm{P}_{2} \mathrm{~W}_{{ }_{18}} \mathrm{O}_{62}\right]^{6}$.

\begin{tabular}{|c|c|}
\hline Solution composition (molar ratio) & $D\left(\mu \mathbf{m}^{2} / \mathbf{s}\right)$ \\
\hline$\gamma-\mathbf{C D}$ & $235 \pm 1$ \\
\hline$\gamma-\mathbf{C D} /\left\{\mathbf{P}_{2} \mathbf{W}_{18}\right\}(\mathbf{2} / \mathbf{1})$ & $187 \pm 1$ \\
\hline$\gamma-\mathbf{C D} /\left\{\mathbf{R e}_{6}{ }^{a \mathrm{an}}\right\}(\mathbf{2} / \mathbf{1})$ & $205 \pm 3$ \\
\hline$\gamma-\mathbf{C D} /\left\{\mathbf{R e}_{\mathrm{c}}{ }^{\mathrm{an}}\right\} /\left\{\mathbf{P}_{2} \mathbf{W}_{\mathrm{ls}}\right\}(\mathbf{2} / \mathbf{1} / \mathbf{1})$ & $198 \pm 3$ \\
\hline$\gamma-\mathbf{C D} /\left\{\boldsymbol{R e}_{\mathrm{c}}^{\mathrm{ca}}\right\}(\mathbf{2} / \mathbf{1})$ & $210 \pm 4$ \\
\hline$\gamma-\mathbf{C D} /\left\{\boldsymbol{R e}_{6}{ }^{\mathrm{c}} \mathrm{u}\right\} /\left\{\mathbf{P}_{2} \mathbf{W}_{\mathrm{s}}\right\}(\mathbf{2} / \mathbf{1} / \mathbf{1})$ & $173 \pm 7$ \\
\hline
\end{tabular}

"Solutions equilibrated for $24 \mathrm{~h}$.

\section{CONCLUSION}

Herein, we report the crystal engineering of CLUSPOM compounds resulting from the supramolecular aggregation of an electron-poor polyoxometalate and an electron-rich rhenium 
cluster. Using a "classical" synthetic approach based on long-range coulombic interactions between a macro-anion $\left(\left[\mathrm{P}_{2} \mathrm{~W}_{18} \mathrm{O}_{62}\right]^{-}\right)$and a macro-cation $\left(\left[\left\{\mathrm{Re}_{6} \mathrm{Se}_{8}\right\}\left(\mathrm{H}_{2} \mathrm{O}\right)_{6}\right]^{2+}\right)$, a ${ }^{6} \mathrm{CLUSPOM}$ salt' was successfully isolated from aqueous mixtures without supramolecular structure-directing agent. On the other hand, using an innovative strategy consisting in cyclodextrin-driven assembling, a hierarchical CLUSPOM architecture was designed in a predictive way. In addition, we reported that presence of $\gamma$-CD provides "counter-intuitive" association containing both $\left[\mathrm{P}_{2} \mathrm{~W}_{18} \mathrm{O}_{62}\right]^{6-}$ and $\left[\left\{\mathrm{Re}_{6} \mathrm{Se}_{8}\right\}(\mathrm{CN})_{6}\right]^{4-}$ anions into a supramolecular edifice. These results evidence that cyclodextrin behaves as efficient supramolecular connector to assemble together polymetallic unit in the solid-state. Solution investigations by complementary techniques (multinuclear and DOSY NMR, and SAXS) revealed however that aggregation of the molecular components results from processes in competition including short-range supramolecular recognition and long-range coulombic attraction/repulsion forces. Interestingly, although the CLUSPOM compounds prepared in this study are built from luminescent rhenium clusters, all these solids are non-emissive when irradiated with UV light $(\lambda=365 \mathrm{~nm})$, suggesting an efficient quenching process in the presence of the electron-acceptor POM. Further work on cyclodextrin-assisted aggregation of functional polymetallic units, namely the CLUSPOM compounds, is underway.

\section{ASSOCIATED CONTENT}

\section{Supporting Information}

The Supporting Information is available free of charge on the ACS Publications website.

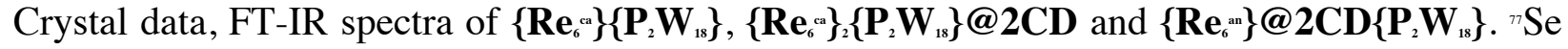
and ${ }^{183}$ W NMR spectra. Simulated SAXS curves. 
Accession Codes: CCDC 1995746-1995749 contain the supplementary crystallographic data for this paper. These data can be obtained free of charge viawww.ccdc.cam.ac.uk/data_request/cif.

\section{AUTHOR INFORMATION}

\section{Corresponding Author}

*E-mail: clement.falaise@uvsq.fr

\section{Notes}

The authors declare no competing financial interest.

\section{ACKNOWLEDGMENT}

We thank Javier Perez for assistance in using beamline SWING. We acknowledge SOLEIL Synchrotron for providing beamtime and synchrotron radiation facilities. Authors gratefully acknowledge financial support from IRP-CNRS CLUSPOM, CNRS MOMENTUM and LabEx CHARMMMAT (grant number ANR-11-LBX-0039). This work was also supported by i) University of Versailles Saint Quentin, ii) CNRS, iii) Région Ile de France through DIM Nano K. NIIC thanks the Ministry of Science and Education of the Russian Federation. A.A. Ivanov and A. A. Shmakova thank Embassy of France in Russia for the Vernadsky scholarship for postgraduate students.

\section{REFERENCES}

(1) Long, D.-L.; Tsunashima, R.; Cronin, L. Polyoxometalates: Building Blocks for Functional Nanoscale Systems. Angew. Chem. Int. Ed. 2010, 49 (10), 1736-1758

(2) Jena, P.; Sun, Q. Super Atomic Clusters: Design Rules and Potential for Building Blocks of Materials. Chem. Rev. 2018, 118 (11), 5755-5870 
(3) Molard, Y. Clustomesogens: Liquid Crystalline Hybrid Nanomaterials Containing Functional Metal Nanoclusters. Acc. Chem. Res. 2016, 49 (8), 1514-1523.

(4) Gumerova, N. I.; Rompel, A. Synthesis, Structures and Applications of Electron-Rich Polyoxometalates. Nat. Rev. Chem. 2018, 2 (2), 1-20

(5) Cadot, E.; Sokolov, M. N.; Fedin, V. P.; Simonnet-Jégat, C.; Floquet, S.; Sécheresse, F. A Building Block Strategy to Access Sulfur-Functionalized Polyoxometalate Based Systems Using $\left\{\mathrm{Mo}_{2} \mathrm{~S}_{2} \mathrm{O}_{2}\right\}$ and $\left\{\mathrm{Mo}_{3} \mathrm{~S}_{4}\right\}$ as Constitutional Units, Linkers or Templates. Chem. Soc. Rev. 2012, 41 (22), 7335-7353

(6) Pinkard, A.; Champsaur, A. M.; Roy, X. Molecular Clusters: Nanoscale Building Blocks for Solid-State Materials. Acc. Chem. Res. 2018, 51 (4), 919-929

(7) Uchida, S.; Mizuno, N. Design and Syntheses of Nano-Structured Ionic Crystals with Selective Sorption Properties. Coord. Chem. Rev. 2007, 251 (21), 2537-2546

(8) Roy, X.; Lee, C.-H.; Crowther, A. C.; Schenck, C. L.; Besara, T.; Lalancette, R. A.; Siegrist, T.; Stephens, P. W.; Brus, L. E.; Kim, P.; Steigerwald, M. L.; Nuckolls, C. Nanoscale Atoms in Solid-State Chemistry. Science 2013, 341 (6142), 157-160

(9) Xiao, Y.; Wang, Q.-M. Luminescence Responsive Charge Transfer Intercluster Crystals. Chem.-Eur. J. 2012, 18 (36), 11184-11187

(10) Uchida, S. Frontiers and Progress in Cation-Uptake and Exchange Chemistry of Polyoxometalate-Based Compounds. Chem. Sci. 2019, 10 (33), 7670-7679

(11) Turkiewicz, A.; Paley, D. W.; Besara, T.; Elbaz, G.; Pinkard, A.; Siegrist, T.; Roy, X. Assembling Hierarchical Cluster Solids with Atomic Precision. J. Am. Chem. Soc. 2014, 136 (45), 15873-15876 
(12) Son, J.-H.; Choi, H.; Kwon, Y.-U. Porous Crystal Formation from Polyoxometalate Building Blocks: $\quad$ Single-Crystal $\quad$ Structure $\left[\mathrm{AlO}_{4} \mathrm{Al}_{12}(\mathrm{OH})_{12}\left(\mathrm{H}_{2} \mathrm{O}\right)_{24}\right]\left[\mathrm{Al}(\mathrm{OH})_{6} \mathrm{Mo}_{6} \mathrm{O}_{18}\right]_{2}\left((\mathrm{OH}) 29.5 \mathrm{H}_{2} \mathrm{O}\right.$. J. Am. Chem. Soc. 2000, $122(30), 7432-$ 7433

(13) Gruber, F.; Jansen, M. Salt-like Structures of Oligomeric Gold Complexes and Polyoxometalates. Z. Für Anorg. Allg. Chem. 2010, 636 (13-14), 2352-2356

(14) Yoshinari, N.; Yamashita, U.; Konno, T. A 1:1 Intercluster Compound Consisting of +6 and -6 Charged Rh III 4 Zn II 4 Octanuclear Cations and Anions with Aminothiolate Ligands. CrystEngComm 2013, 15 (46), 10016-10019

(15) Falaise, C.; Hickam, S. M.; Burns, P. C.; Nyman, M. From Aqueous Speciation to Supramolecular Assembly in Alkaline Earth-Uranyl Polyoxometalates. Chem. Commun. 2017, $53(69), 9550-9553$

(16) Kawamoto, R.; Uchida, S.; Mizuno, N. Amphiphilic Guest Sorption of $\mathrm{K}_{2}\left[\mathrm{Cr}_{3} \mathrm{O}\left(\mathrm{OOCC}_{2} \mathrm{H}_{5}\right)_{6}\left(\mathrm{H}_{2} \mathrm{O}\right)_{3}\right]_{2}\left[\alpha-\mathrm{SiW}_{12} \mathrm{O}_{40}\right]$ Ionic Crystal. J. Am. Chem. Soc. 2005, 127 (30), 1056010567

(17) Uchida, S.; Hashimoto, M.; Mizuno, N. A Breathing Ionic Crystal Displaying Selective Binding of Small Alcohols and Nitriles: $\mathrm{K}_{3}\left[\mathrm{Cr}{ }_{3} \mathrm{O}(\mathrm{OOCH})_{6}\left(\mathrm{H}_{2} \mathrm{O}\right)_{3}\right]\left[\alpha-\mathrm{SiW}_{12} \mathrm{O}_{40}\right] \cdot 16 \mathrm{H}_{2} \mathrm{O}$. Angew . Chem. Int. Ed. 2002, 41 (15), 2814-2817

(18) Liu, K.-G.; Liu, X.-Y.; Guan, Z.-J.; Shi, K.; Lin, Y.-M.; Wang, Q.-M. The Transformation of Polyoxometalates in the Formation of Intercluster Compound $\operatorname{Ag}_{41}(\alpha-$ $\left.\left.\mathrm{SiW}_{10} \mathrm{O}_{37}\right)(\mathrm{TBuCC})_{27}\left(\mathrm{CH}_{3} \mathrm{CN}\right)_{3}\right]\left[\beta-\mathrm{SiW}_{12} \mathrm{O}_{40}\right]$. Chem. Commun. 2016, 52 (19), 3801-3804

(19) Gruber, F.; Schulz Dobrick, M.; Jansen, M. Structure-Directing Forces in Intercluster Compounds of Cationic $\left[\mathrm{Ag}_{14}(\mathrm{CCtBu})_{12} \mathrm{Cl}\right]^{+}$Building Blocks and Polyoxometalates: Long-Range versus Short-Range Bonding Interactions. Chem. - Eur. J. 2010, 16 (5), 1464-1469 
(20) Gruber, F.; Jansen, M. Packing Requirements and Short-Range Interactions as StructureDirecting Forces in the Intercluster Compounds Based on Silver Clusters. Inorganica Chim. Acta 2010, 363 (15), 4282-4286

(21) Schulz-Dobrick, M; Jansen, M. Structure-Directing Effects in the Supramolecular Intercluster Compound $\left[\mathrm{Au}_{9}\left(\mathrm{PPh}_{3}\right)_{8}\right]_{2}\left[\mathrm{~V}_{10} \mathrm{O}_{28} \mathrm{H}_{3}\right]_{2}$ : Long-Range versus Short-Range Bonding Interactions. Inorg. Chem. 2007, 46 (11), 4380-4382

(22) Wang, S.-S.; Yang, G.-Y. Recent Advances in Polyoxometalate-Catalyzed Reactions. Chem. Rev. 2015, 115 (11), 4893-4962

(23) Son, J. H.; Kwon, Y.-U.; Han, O. H. New Ionic Crystals of Oppositely Charged Cluster Ions and Their Characterization. Inorg. Chem. 2003, 42 (13), 4153-4159

(24) Son, J.-H.; Kwon, Y.-U. Crystal Engineering through Face Interactions between Tetrahedral and Octahedral Building Blocks: Crystal Structure of $[\varepsilon$ $\left.\mathrm{Al}_{13} \mathrm{O}_{4}(\mathrm{OH})_{24}\left(\mathrm{H}_{2} \mathrm{O}\right)_{12}\right]_{2}\left[\mathrm{~V}_{2} \mathrm{~W}_{4} \mathrm{O}_{19}\right]_{3}(\mathrm{OH})_{2} \cdot 27 \mathrm{H}_{2} \mathrm{O}$. Inorg. Chem. 2004, $43(6), 1929-1932$

(25) Son, J.-H.; Kwon, Y.-U. Polymorphism in Intercluster Salt System: Two Crystal Structures of $\left[\mathrm{Al}_{13} \mathrm{O}_{4}(\mathrm{OH})_{24}\left(\mathrm{H}_{2} \mathrm{O}\right)_{12}\right]\left[\mathrm{H}_{2} \mathrm{~W}_{12} \mathrm{O}_{40}\right](\mathrm{OH}) \cdot \mathrm{nH}_{2} \mathrm{O}$. Inorganica Chim. Acta 2005, 358 (2), $310-314$

(26) Mizuno, K.; Mura, T.; Uchida, S. Control of Polymorphisms and Functions in AllInorganic Ionic Crystals Based on Polyaluminum Hydroxide and Polyoxometalates. Cryst. Growth Des. 2016, 16 (9), 4968-4974

(27) Ibrahim, M.; Dickman, M. H.; Suchopar, A.; Kortz, U. Large Cation-Anion Materials Based on Trinuclear Ruthenium(III) Salts of Keggin and Wells-Dawson Anions Having WaterFilled Channels. Inorg. Chem. 2009, 48 (4), 1649-1654 
(28) Uchida, S.; Mizuno, N. Zeotype Ionic Crystal of $\mathrm{Cs}_{5}\left[\mathrm{Cr}_{3} \mathrm{O}(\mathrm{OOCH})_{6}\left(\mathrm{H}_{2} \mathrm{O}\right)_{3}\right][\alpha-$ $\left.\mathrm{CoW}_{12} \mathrm{O}_{40}\right] \cdot 7.5 \mathrm{H}_{2} \mathrm{O}$ with Shape-Selective Adsorption of Water. J. Am. Chem. Soc. 2004, 126 (6), $1602-1603$

(29) Jiang, C.; Lesbani, A.; Kawamoto, R.; Uchida, S.; Mizuno, N. Channel-Selective Independent Sorption and Collection of Hydrophilic and Hydrophobic Molecules by $\mathrm{Cs}_{2}\left[\mathrm{Cr}_{3} \mathrm{O}\left(\mathrm{OOCC}_{2} \mathrm{H}_{5}\right)_{6}\left(\mathrm{H}_{2} \mathrm{O}\right)_{3}\right]_{2}\left[\alpha-\mathrm{SiW}_{12} \mathrm{O}_{40}\right]$ Ionic Crystal. J. Am. Chem. Soc. 2006, $128(44), 14240-$ 14241

(30) Tagami, H.; Uchida, S.; Mizuno, N. Size-Selective Sorption of Small Organic Molecules in One-Dimensional Channels of an Ionic Crystalline Organic-Inorganic Hybrid Compound Stabilized by $\pi-\pi$ Interactions. Angew. Chem. Int. Ed. 2009, 48 (33), 6160-6164

(31) Uchida, S.; Eguchi, R.; Mizuno, N. Zeotype Organic-Inorganic Ionic Crystals: Facile Cation Exchange and Controllable Sorption Properties. Angew. Chem. Int. Ed. 2010, 49 (51), 9930-9934

(32) Eguchi, R.; Uchida, S.; Mizuno, N. Inverse and High $\mathrm{CO}_{2} / \mathrm{C}_{2} \mathrm{H}_{2}$ Sorption Selectivity in Flexible Organic-Inorganic Ionic Crystals. Angew. Chem. Int. Ed. 2012, 51 (7), 1635-1639

(33) Seino, S.; Kawahara, R.; Ogasawara, Y.; Mizuno, N.; Uchida, S. Reduction-Induced Highly Selective Uptake of Cesium Ions by an Ionic Crystal Based on Silicododecamolybdate. Angew. Chem. Int. Ed. 2016, 55 (12), 3987-3991

(34) Hitose, S.; Uchida, S. Rapid Uptake/Release of Cs+ in Isostructural Redox-Active Porous Ionic Crystals with Large-Molecular-Size and Easily Reducible Dawson-Type Polyoxometalates as Building Blocks. Inorg. Chem. 2018, 57 (9), 4833-4836

(35) Schulz Dobrick, M.; Jansen, M. Supramolecular Intercluster Compounds Consisting of Gold Clusters and Keggin Anions. Eur. J. Inorg. Chem. 2006, 2006 (22), 4498-4502 
(36) Schulz Dobrick, M.; Jansen, M. Characterization of Gold Clusters by Crystallization with Polyoxometalates: The Intercluster Compounds $\left.\left[\mathrm{Au}_{9}(\mathrm{Dpph})_{4}\right]\left[\mathrm{Mo}_{8} \mathrm{O}_{26}\right],\left[\mathrm{Au}_{9} \mathrm{Dpph}\right)_{4}\right]\left[\mathrm{PW}_{12} \mathrm{O}_{40}\right]$ and $\left[\mathrm{Au}_{11}\left(\mathrm{PPh}_{3}\right)_{8} \mathrm{Cl}_{2}\right]_{2}\left[\mathrm{~W}_{6} \mathrm{O}_{19}\right]$. Z. Für Anorg. Allg. Chem. 2007, 633 (13-14), 2326-2331

(37) Schulz Dobrick, M.; Jansen, M. Synthesis and Characterization of Intercluster Compounds Consisting of Various Gold Clusters and Differently Charged Keggin Anions. Z. Für Anorg. Allg. Chem. 2008, 634 (15), 2880-2884

(38) Nomiya, K.; Yoshida, T.; Sakai, Y.; Nanba, A.; Tsuruta, S. Intercluster Compound between a Tetrakis $\{$ triphenylphosphinegold(I)\}oxonium Cation and a Keggin Polyoxometalate (POM): Formation during the Course of Carboxylate Elimination of a Monomeric Triphenylphosphinegold(I) Carboxylate in the Presence of POMs. Inorg. Chem. 2010, 49 (18), $8247-8254$

(39) Yoshida, T.; Matsunaga, S.; Nomiya, K. Two Types of Tetranuclear Phosphanegold(I) Cations as Dimers of Dinuclear Units, $\left[\left\{\left(\mathrm{Au}\left\{\mathrm{P}(\mathrm{p}-\mathrm{RPh})_{3}\right\}\right)_{2}(\mu-\mathrm{OH})\right\}_{2}\right]^{2+}(\mathrm{R}=\mathrm{Me}, \mathrm{F})$, Synthesized by Polyoxometalate-Mediated Clusterization. Dalton Trans. 2013, 42 (32), 11418-11425

(40) Yoshida, T.; Yasuda, Y.; Nagashima, E.; Arai, H.; Matsunaga, S.; Nomiya, K. Various Oxygen-Centered Phosphanegold(I) Cluster Cations Formed by Polyoxometalate (POM)Mediated Clusterization: Effects of POMs and Phosphanes. Inorganics 2014, 2 (4), 660-673

(41) Moussawi, M. A.; Leclerc-Laronze, N.; Floquet, S.; Abramov, P. A.; Sokolov, M. N.; Cordier, S.; Ponchel, A.; Monflier, E.; Bricout, H.; Landy, D.; Haouas, M.; Marrot, J.; Cadot, E. Polyoxometalate, Cationic Cluster, and $\gamma$-Cyclodextrin: From Primary Interactions to Supramolecular Hybrid Materials. J. Am. Chem. Soc. 2017, 139 (36), 12793-12803

(42) Wu, Y.; Shi, R.; Wu, Y.-L.; Holcroft, J. M.; Liu, Z.; Frasconi, M.; Wasielewski, M. R.; Li, H.; Stoddart, J. F. Complexation of Polyoxometalates with Cyclodextrins. J. Am. Chem. Soc. 2015, 137 (12), 4111-4118 
(43) Assaf, K. I.; Ural, M. S.; Pan, F.; Georgiev, T.; Simova, S.; Rissanen, K.; Gabel, D.; Nau, W. M. Water Structure Recovery in Chaotropic Anion Recognition: High-Affinity Binding of Dodecaborate Clusters to $\gamma$-Cyclodextrin. Angew. Chem. Int. Ed. 2015, 54 (23), 6852-6856

(44) Falaise, C.; Moussawi, M. A.; Floquet, S.; Abramov, P. A.; Sokolov, M. N.; Haouas, M.; Cadot, E. Probing Dynamic Library of Metal-Oxo Building Blocks with $\gamma$-Cyclodextrin. J. Am. Chem. Soc. 2018, 140 (36), 11198-11201

(45) Ivanov, A. A.; Falaise, C.; Abramov, P. A.; Shestopalov, M. A.; Kirakci, K.; Lang, K.; Moussawi, M. A.; Sokolov, M. N.; Naumov, N. G.; Floquet, S.; Landy, D.; Haouas, M.; Brylev, K. A.; Mironov, Y. V.; Molard, Y.; Cordier, S.; Cadot, E. Host-Guest Binding Hierarchy within Redox- and Luminescence-Responsive Supramolecular Self-Assembly Based on Chalcogenide Clusters and $\gamma$-Cyclodextrin. Chem. - Eur. J. 2018, 24 (51), 13467-13478

(46) Ivanov, A. A.; Falaise, C.; Landy, D.; Haouas, M.; Mironov, Y. V.; Shestopalov, M. A.; Cadot, E. Tuning the Chaotropic Effect as an Assembly Motif through One-Electron Transfer in a Rhenium Cluster. Chem. Commun. 2019, 55 (67), 9951-9954

(47) Ivanov, A. A.; Falaise, C.; Laouer, K.; Hache, F.; Changenet, P.; Mironov, Y. V.; Landy, D.; Molard, Y.; Cordier, S.; Shestopalov, M. A.; Haouas, M.; Cadot, E. Size-Exclusion Mechanism Driving Host-Guest Interactions between Octahedral Rhenium Clusters and Cyclodextrins. Inorg. Chem. 2019, 58 (19), 13184-13194

(48) Moussawi, M. A.; Haouas, M.; Floquet, S.; Shepard, W. E.; Abramov, P. A.; Sokolov, M. N.; Fedin, V. P.; Cordier, S.; Ponchel, A.; Monflier, E.; Marrot, J.; Cadot, E. Nonconventional Three-Component Hierarchical Host-Guest Assembly Based on Mo-Blue Ring-Shaped Giant Anion, $\gamma$-Cyclodextrin, and Dawson-Type Polyoxometalate. J. Am. Chem. Soc. 2017, 139 (41)

(49) Assaf, K. I.; Nau, W. M. The Chaotropic Effect as an Assembly Motif in Chemistry. Angew. Chem. Int. Ed. 2018, 57 (43), 13968-13981 
(50) Cordier, S.; Molard, Y.; Brylev, K. A.; Mironov, Y. V.; Grasset, F.; Fabre, B.; Naumov, N. G. Advances in the Engineering of Near Infrared Emitting Liquid Crystals and Copolymers, Extended Porous Frameworks, Theranostic Tools and Molecular Junctions Using Tailored Re6 Cluster Building Blocks. J. Clust. Sci. 2015, 26 (1), 53-81

(51) Mbomekalle, I.-M.; Lu, Y. W.; Keita, B.; Nadjo, L. Simple, High Yield and ReagentSaving Synthesis of Pure $\alpha-\mathrm{K}_{6} \mathrm{P}_{2} \mathrm{~W}_{18} \mathrm{O}_{62} \cdot 14 \mathrm{H}_{2} \mathrm{O}$. Inorg. Chem. Commun. 2004, 7 (1), 86-90

(52) Naumov, N. G.; Virovets, A. V.; Podberezskaya, N. V.; Fedorov, V. E. Synthesis and Crystal Structure of $\mathrm{K}_{4}\left[\operatorname{Re}_{6} \mathrm{Se}_{8}(\mathrm{CN})_{6}\right] \cdot 3.5 \mathrm{H}_{2} \mathrm{O}$. J. Struct. Chem. 1997, 38 (5), 857-862

(53) Yarovoi, S. S.; Mironov, Y. V.; Naumov, D. Y.; Gatilov, Y. V.; Kozlova, S. G.; Kim, S.J.; Fedorov, V. E. Octahedral Hexahydroxo Rhenium Cluster Complexes $\left[\operatorname{Re}_{6} Q_{8}(O H)_{6}\right]^{+\cdot}(Q=S$, Se): Synthesis, Structure, and Properties. Eur. J. Inorg. Chem. 2005, 2005 (19), 3945-3949

(54) Dolomanov, O. V.; Bourhis, L. J.; Gildea, R. J.; Howard, J. a. K.; Puschmann, H. OLEX2: A Complete Structure Solution, Refinement and Analysis Program. J. Appl. Crystallogr. 2009, 42 (2), 339-341

(55) Sheldrick, G. M. SHELXT - Integrated Space-Group and Crystal-Structure Determination. Acta Crystallogr. Sect. Found. Adv. 2015, 71 (1), 3-8

(56) Sheldrick, G. M. Crystal Structure Refinement with SHELXL. Acta Crystallogr. Sect. C Struct. Chem. 2015, 71 (1), 3-8

(57) Harris, R. K.; Becker, E. D.; Menezes, S. M. C. de; Goodfellow, R.; Granger, P. NMR Nomenclature. Nuclear Spin Properties and Conventions for Chemical Shifts (IUPAC Recommendations 2001). Pure Appl. Chem. 2001, 73 (11), 1795-1818

(58) Zhang, R.; Thiyagarajan, P.; Tiede, D. M. Probing Protein Fine Structures by Wide Angle Solution X-Ray Scattering. J. Appl. Crystallogr. 2000, 33 (3-1), 565-568 
(59) Alsén, N. Röntgenographische Untersuchung Der Kristallstrukturen von Magnetkies, Breithauptit, Pentlandit, Millerit Und Verwandten Verbindungen. Geol. Fören. Stockh. Förh. 1925, $47(1), 19-72$

(60) Abramov, P. A.; Ivanov, A. A.; Shestopalov, M. A.; Moussawi, M. A.; Cadot, E.; Floquet, S.; Haouas, M.; Sokolov, M. N. Supramolecular Adduct of $\gamma$-Cyclodextrin and $\left[\left\{\operatorname{Re}_{6} \mathrm{Q}_{8}\right\}\left(\mathrm{H}_{2} \mathrm{O}\right)_{6}\right]^{2+}(\mathrm{Q}=\mathrm{S}, \mathrm{Se})$. J. Clust. Sci. 2018, $29(1), 9-13$

(61) Miras, H. N.; Cooper, G. J. T.; Long, D.-L.; Bögge, H.; Müller, A.; Streb, C.; Cronin, L. Unveiling the Transient Template in the Self-Assembly of a Molecular Oxide Nanowheel. Science 2010, 327 (5961), 72-74

(62) Fang, X.; Hansen, L.; Haso, F.; Yin, P.; Pandey, A.; Engelhardt, L.; Slowing, I.; Li, T.; Liu, T.; Luban, M.; Johnston, D. C. $\mathrm{Mo}_{24} \mathrm{Fe}_{12}$ Macrocycles: Anion Templation with Large Polyoxometalate Guests. Angew. Chem. Int. Ed. 2013, 52 (40), 10500-10504

(63) Xuan, W.; Surman, A. J.; Zheng, Q.; Long, D.-L.; Cronin, L. Self-Templating and In Situ Assembly of a Cubic Cluster-of-Clusters Architecture Based on a $\mathrm{Mo}_{24} \mathrm{Fe}_{12}$ Inorganic Macrocycle. Angew. Chem. Int. Ed. 2016, 55 (41), 12703-12707

(64) Xuan, W.; Pow, R.; Watfa, N.; Zheng, Q.; Surman, A. J.; Long, D.-L.; Cronin, L. Stereoselective Assembly of Gigantic Chiral Molybdenum Blue Wheels Using Lanthanide Ions and Amino Acids. J. Am. Chem. Soc. 2019, 141 (3), 1242-1250

(65) Nyman, M. Small-Angle X-Ray Scattering to Determine Solution Speciation of MetalOxo Clusters. Coord. Chem. Rev. 2017, 352, 461-472 


\section{For Table of Contents Use Only.}

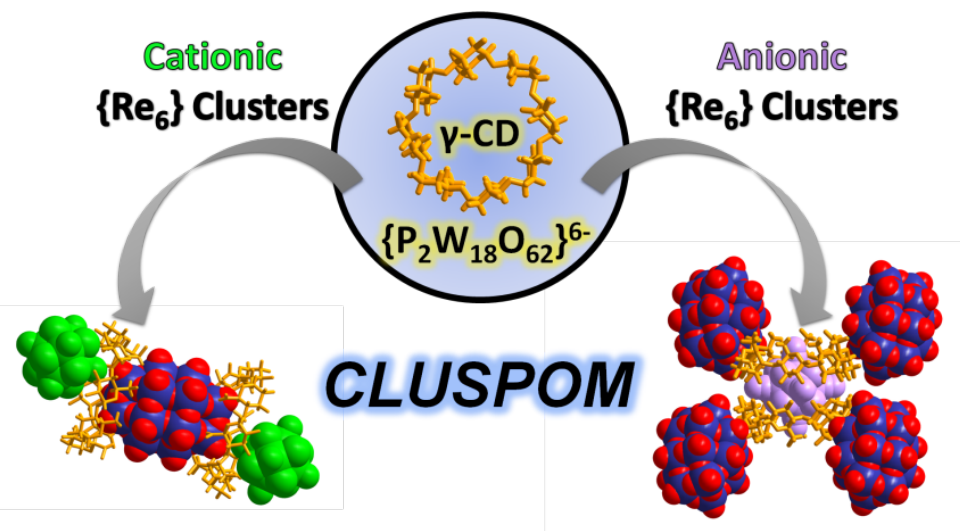

This study evidences that $\gamma$-cyclodextrin, a natural macrocyclic polysaccharide, behaves as efficient supramolecular connector to assemble an electron-poor polyoxometalate $\left(\left[\mathrm{P}_{2} \mathrm{~W}_{18} \mathrm{O}_{62}\right]^{6}\right)$ and electron-rich rhenium cluster $\left(\left[\left\{\mathrm{Re}_{6} \mathrm{Se}_{8}\right\}\left(\mathrm{H}_{2} \mathrm{O}\right)_{6}\right]^{2+}\right.$ or $\left.\left[\left\{\mathrm{Re}_{6} \mathrm{Se}_{8}\right\}(\mathrm{CN})_{6}\right]^{+}\right)$in the solid-state. However, solution investigations revealed that aggregation of the preformed molecular components results from processes in competition including short-range supramolecular recognition or long-range coulombic attraction/repulsion forces. 